\title{
Los bienes de las parroquias altoaragonesas en el Museo de Lérida: de sentencias e intenciones
}

\author{
MARÍA José NAVARRo BOMETÓN ${ }^{1}$ \\ The Artistic Heritage from the High Aragon District in the \\ Museum of Lérida: Rulings and Intentions
}

\begin{abstract}
RESUMEN
En 1995, tras la reforma de los límites diocesanos entre las antiguas sedes episcopales de Lérida y Barbastro, se ponía en marcha un litigio canónico por la propiedad de los bienes artísticos procedentes de las parroquias altoaragonesas que, desde finales del siglo XIX, fueron trasladados al Museo del Seminario ilerdense, después Museo Diocesano. La Nunciatura Apostólica decretó en 1998 que las piezas estaban en Lérida a título de depósito y que la propiedad pertenecía a las parroquias que habían pasado a formar parte de la diócesis de Barbastro-Monzón. El litigio canónico se zanjó en 2007, pero actualmente las piezas protagonizan varias causas en los tribunales civiles, entre las que destacan las abiertas por dos ayuntamientos cuyas parroquias pertenecen, desde 1955, a la diócesis de Huesca.

Algunos de los bienes en litigio tienen un notable valor artístico, pero es su valor como símbolo histórico y de identidad, como herencia del esfuerzo y de la devoción de unas comunidades rurales, lo que reclaman los aragoneses. Así mismo, las instituciones catalanas, abogan por la propiedad de unas piezas cuya conservación fue posible gracias a la labor del obispado de Lérida.
\end{abstract}

\begin{abstract}
In 1995 after the reform of the diocesan boundaries between the former Episcopal sees of Lérida and Barbastro a canonical dispute was initiated in order to establish the property of the artistic goods from the High Aragon, which at the end of the $19^{\text {th }}$ century were moved to the Seminary Museum of Lerida, called afterwards Diocesan Museum. The Apostolic Nunciature decreed in 1998 that the pieces were in Lérida in storage and that they belonged to the parishes which had formed part of the diocese BarbastroMonzón. The canonical dispute ended in 2007, but the pieces are involved presently in several civil court cases, among which are those opened by two councils whose parishes belong since 1955 to the Diocese of Huesca. Some of the historical and disputed goods have an extremely high artistic value, but it is their value as an historical and identitary symbol inherited with great effort and devotion by the rural communities, which is demanded by the Aragonese. Furthermore, the Catalan institutions are disputing for the property rights of the pieces, which were preserved thanks to the work of the Bishopric of Lérida.
\end{abstract}

\footnotetext{
1 Licenciada en Geografía e Historia y alumna de Doctorado de Historia del Arte de la UNED.
} 
PALABRAS CLAVE:

patrimonio eclesiástico; litigio por los bienes; diócesis de Barbastro-Monzón; diócesis de Lérida; diócesis de Huesca;

Museo Diocesano.
KEY WORDS:

ecclesiastic heritage; dispute for the artistic goods; Diocese of BarbastroMonzón; Diocese of Lérida; Diocese of Huesca; Diocesan Museum.

\section{HISTORIA DE UN DESENCUENTRO}

Por circunstancias que se irán explicando en estas páginas se hallan entre las colecciones del actual Museo de Lérida, Diocesano y Comarcal (MLDC) un número todavía indeterminado de obras de arte y objetos de culto religioso procedentes de las poblaciones de la parte oriental de la provincia de Huesca. La mayoría de ellos fueron trasladados a Lérida, desde sus parroquias de origen, a partir 1893 por iniciativa del obispo José Meseguer y Costa. Diferentes instituciones solicitan su regreso a tierras aragonesas oficialmente desde 1995, aunque con anterioridad existían voces que, desde distintos foros, requerían este retorno.

Pueden distinguirse dos vías principales de reclamación: una, la que se llevó a cabo desde la diócesis de Barbastro-Monzón, que partió de la iniciativa eclesiástica y generó un litigio canónico y, otra, la que se hace por parte de las poblaciones pertenecientes a esta y a la vecina diócesis de Huesca, que se emprendió desde instituciones civiles. Es el caso de los ayuntamientos de Berbegal y Peralta de Alcofea que, a su vez, instaron el apoyo de sus respectivas parroquias y del obispado de Huesca, y del ayuntamiento de Villanueva de Sijena, que también se ha pronunciado en demanda de las piezas del Real Monasterio de Santa María de Sijena².

\subsection{La segregación de las parroquias aragonesas}

Por Decreto de la Congregación para los obispos «llerdensis-Barbastrensis de finium mutatione» de 15 de junio de 1995, las parroquias aragonesas adscritas a la diócesis de Lérida (fig. 1) quedaban desmembradas de esta y agregadas a la diócesis de Barbastro, que en adelante llevaría el título de Barbastro-Monzón ${ }^{3}$. Esta reforma de límites suponía la culminación de un proceso iniciado tras el Concordato de 1953 que pretendía ajustar los límites diocesanos a las demarcaciones administrativas provinciales ${ }^{4}$. Se cumplía así una vieja aspiración del clero y los feli-

\footnotetext{
2 Por el momento no son objeto de reclamación institucional los objetos litúrgicos que, procedentes de la ex catedral de Roda de Isábena fueron, desde mediados de siglo XIX trasladados a Lérida en varias ocasiones y que actualmente forman parte del Tesoro de la Seu Nova de Lérida.

${ }_{3}$ Por este Decreto se transferían desde la diócesis de Lérida a la diócesis de Barbastro, que desde ahora pasaría denominarse diócesis de Barbastro-Monzón, un total de 111 parroquias pertenecientes a los arciprestazgos de Ribagorza Occidental, Ribagorza Oriental, Cinca Medio, La Litera y Bajo Cinca.

4 En 1955, de acuerdo con el art. 9 del Concordato, ya se segregaron de la diócesis catalana 35 parroquias de territorio aragonés, de ellas 2 pasaron a la diócesis de Zaragoza, 17 a la entonces diócesis de Barbastro y otras 15, que pertenecían al arciprestazgo de Berbegal, a la diócesis de Huesca.
} 
greses de las parroquias orientales de la provincia de Huesca que veían su situación de dependencia de la diócesis catalana como un anacronismo de la Iglesia 5 .

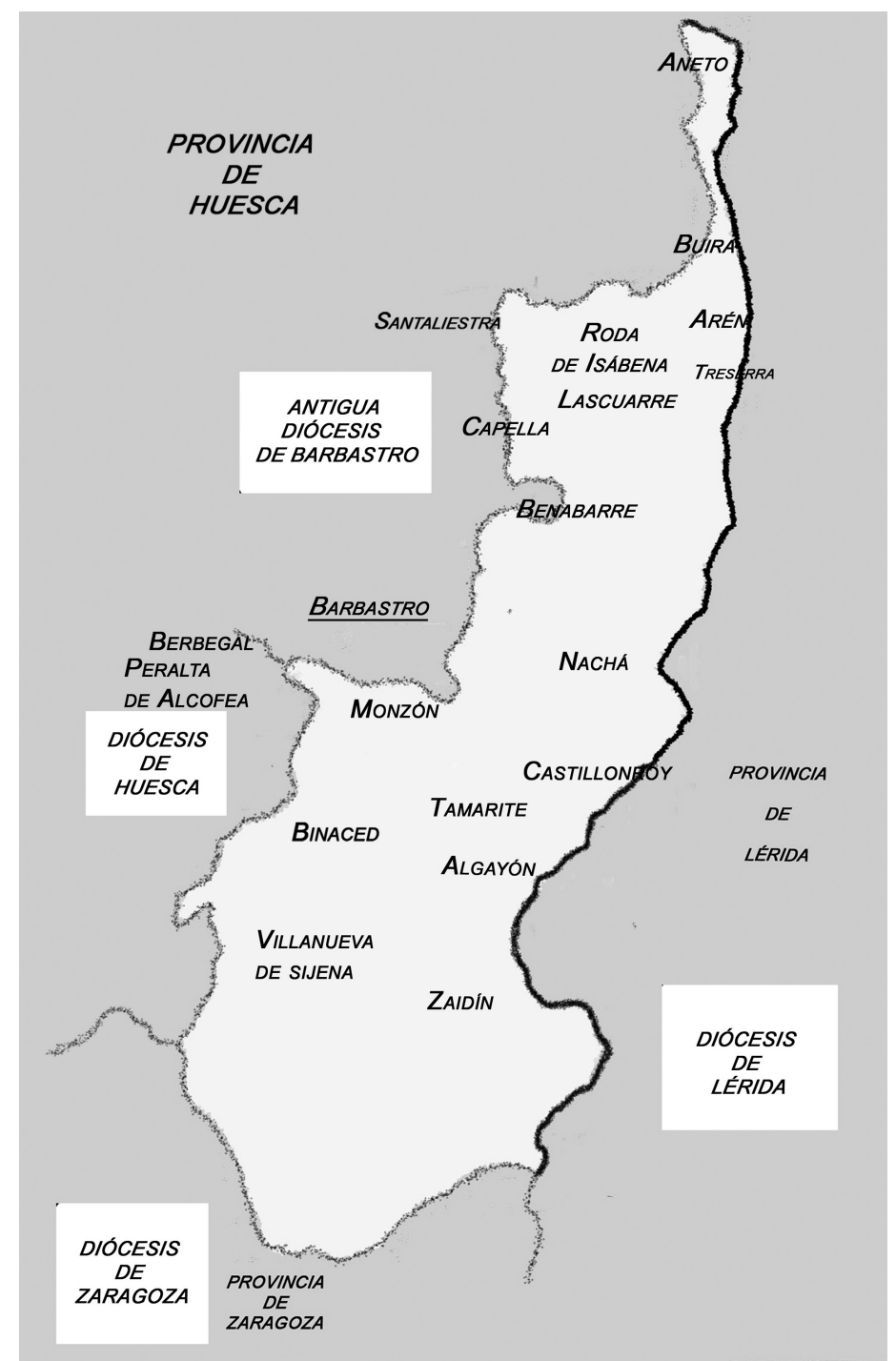

Fig. 1. Mapa de la zona oriental de la provincia de Huesca. En color más claro, el territorio oriental de la provincia cuyas parroquias fueron transferidas de la diócesis de Lérida a la de Barbastro-Monzón por el Decreto de la Congregación de los Obispos en 1995.

${ }^{5}$ Las opiniones del clero aragonés sobre el incompleto reajuste de los límites diocesanos en 1955 están explicadas en IGLESIAS COSTA, M. «Así fue lo de la Franja. (Sobre el proceso de la reordenación limítrofe entre las diócesis de Lérida y Barbastro)» en Homenaje a Durán Gudiol, Huesca, 1995, pp. 441. 455; véase también GROS BITRIA, E., Los límites diocesanos del Alto Aragón Oriental, Guara Editorial, Zaragoza, 1980, p. 143. 
Algunos sectores catalanes entienden todavía esta segregación como un injusto error histórico ya que, según plantea entre interrogantes el Manifiesto de la Plataforma Cívica por la unidad del Museo de Lérida, la decisión de segregar las parroquias no tuvo en cuenta ni la historia del territorio ni el sentimiento de unas gentes que tienen -en el parecer de dicha asociación- a Lérida como capital cultural ${ }^{6}$.

Para una parte del clero aragonés, que la segregación no se hubiera completado ya en 1955 obedecía a los intereses políticos catalanes utilizados ante el gobierno franquista temeroso del separatismo catalán. Una encuesta realizada en los años ochenta del pasado siglo entre los feligreses y el clero de las parroquias que todavía quedaban bajo la mitra leridana reflejó su deseo de integrarse a la diócesis aragonesa ${ }^{7}$.

Al respecto, mosén Eladio Gros explicaba en 1980 que

«...La unión de los sacerdotes de la zona aragonesa en la reivindicación de la pertenencia a la provincia eclesiástica de Aragón es anterior a las Autonomías y a los Estatutos, aunque estos hayan venido a darles mayor consistencia. Esta unión es fruto, en gran parte, de algunas entidades catalanas que, abierta o solapadamente, orquestan campañas colonialistas reclamando esta zona [oriental de la provincia de Huesca] como perteneciente "als paisos catalans"...»8

\subsection{El inicio del conflicto}

El Decreto de la Congregación para los obispos de junio 1995 establecía, entre otros puntos, que habían de transferirse

«...cuanto antes de la Curia de procedencia a la Curia destinataria los Documentos y Libros de Actas de las mencionadas parroquias relacionados con los clérigos, los fieles y los bienes temporales...”

A finales de ese año y mediante un escrito firmado por el Delegado de Patrimonio Cultural del obispado de Barbastro-Monzón dirigido al obispado de Lérida se reclamaron las obras que, según el catálogo de la Exposición Pulchra ${ }^{9}$, procedían de las parroquias recién segregadas. La respuesta de la diócesis de Lérida en ese

6 Manifest de la Plataforma Cívica per la unitat del Museu recolzant l'actuació del bisbe de Lleida, Lérida, 9 de junio de 2010. [En línea] http://www.amicsmuseulleida.org/pages/3-manifests-de-la-plataformacivica-.html [consulta 1 de noviembre de 2010] Texto original en catalán.

7 IGLESIAS COSTA, M., op. cit. pp. 442 y 452.

8 GROS BITRIA, E., op. cit., p. 143.

9 VV.AA., Pulchra. Museu Diocesà de Lleida, 1893-1993, Catálogo de la Exposición, Generalitat de Catalunya, Lérida, 1993. Este catálogo es el mejor compendio publicado hasta el momento de las piezas procedentes de la antigua diócesis de Lérida, aunque de muchos de los objetos no se refiere su población de origen. Las fichas de cada uno de ellos fueron realizadas por expertos historiadores del Arte, si bien existe una copiosa bibliografía específica sobre las piezas más destacadas. 
Los bienes de las parroquias altoaragonesas en el Museo de Lérida: de sentencias...

momento fue que el patrimonio histórico artístico de las parroquias transferidas pertenecía al obispado de Lérida, bien porque había sido comprado a las parroquias a cambio de imágenes u obras de restauración o mantenimiento en dichas parroquias costeadas por el obispo, o bien porque había sido donado por los párrocos al obispado.

Se iniciaba así el litigio por los bienes, un pleito jurídico que compete exclusivamente a la Iglesia en virtud al Acuerdo sobre Asuntos Jurídicos entre el Estado Español y la Santa Sede, de 3 de enero de 1979, art. $1.4^{10}$. El litigio canónico se halla cerrado en la actualidad con la resolución de que los bienes que son propiedad de las parroquias aragonesas se encuentran en el MLDC a título de depósito y deben ser devueltos a la diócesis aragonesa.

\section{3. (Breve) Itinerario del litigio por los bienes ${ }^{11}$}

Para lo que interesa a este artículo se van a mencionar los hitos más importantes del proceso canónico. Un proceso muy importante porque en él se dilucida la propiedad de cada una de las piezas reclamadas y las consideraciones que llevan a dirimir esta titularidad en cada caso y, además, porque en él se establece que los tribunales eclesiásticos son los competentes para resolverlo.

Apenas se había producido la segregación de las parroquias, el obispo de Lérida escribía que

«...por lo que se refiere al patrimonio artístico que se viene reclamando [...] a mi entender, se trata de bienes adquiridos por la diócesis para el Museo Diocesano, mediante entrega, en su día, de cantidades a las Parroquias respectivas, lo que equivalía a una compra [...] En muy pocos casos se trata de bienes depositados

10 Aunque a menudo se ha presentado esta disputa como un pleito entre las dos diócesis, en realidad es un caso de no acatamiento de una orden de gobierno. El camino elegido por la diócesis de Lérida para oponerse a la medida gubernativa fue el proceso contencioso administrativo, tramitado en las instancias eclesiásticas conforme al Derecho Canónico: primero como recurso jerárquico y después como proceso judicial contencioso administrativo ante el órgano supremo, la sectio altera del Tribunal Supremo de la Signatura Apostólica.

${ }^{11}$ El litigio por los bienes de arte sacro es un complejo proceso que ha sido objeto de estudio por numerosos expertos en Derecho. El trabajo de los doctores en Derecho Canónico Federico R. Aznar y Raúl Román recoge el itinerario del litigio eclesiástico y los documentos emanados de él desde 1995 a 2008. Véase AZNAR GIL, F. R. y ROMÁN SÁNCHEZ, R. (coords.), Los bienes artísticos de la Franja: el proceso canónico. (1995-2008), Fundación Teresa de Jesús, Zaragoza, 2009. Este trabajo será de continua referencia en este artículo.

El pleito está breve pero magistralmente explicado por el Vicario Judicial de la Diócesis de Barbastro, véase MORA PELLICER, J., «La devolución de los bienes artísticos de la diócesis de BarbastroMonzón» en Jurídicas XXI, núm. 13, mayo 2008, C Leggio Contenidos y Aplicaciones Informáticas, S.L. [en línea] www.juridicasXXI.com [consulta 27 de noviembre de 2010].

Así mismo, la trascendencia del Decreto definitivo de la Signatura Apostólica, de 28 de abril de 2007, se expone en AZNAR GIL, F. R., "Consideraciones sobre la prescripción adquisitiva de bienes en el derecho canónico a propósito del litigio entre las diócesis de Barbastro-Monzón y Lérida» en Revista española de derecho canónico, CSIC, Universidad Pontificia de Salamanca, Vol. 64, № 163, 2007, pp. 747-800. 
solamente en custodia, para conservarlos mejor. De ahí que me permita pedir que en este tema se acuda al instituto jurídico de la prescripción, o a otra fórmula, que zanjara de raíz cualquier posible polémica o discusión sobre este punto.... ${ }^{12}$

Los abogados de la diócesis de Lérida fundamentaron sus alegaciones en que, con el acto episcopal de traslado de las obras al Museo del Seminario, se había generado un verdadero título de propiedad por contrato de compraventa o de permuta entre las parroquias y el obispo diocesano y, en último caso, aducían que había nacido la propiedad por prescripción ${ }^{13}$ o usucapión, ya que los bienes se habían poseído pacíficamente durante más de cien años. El obispado aragonés, ante esta pretensión y en vista de la respuesta negativa de Lérida a su reivindicación, presentó un recurso jerárquico ante la Nunciatura Apostólica, encargada de ejecutar el Decreto de modificación de límites, para que interviniese en el conflicto sobre la propiedad de los bienes.

Ante la disparidad de criterios entre las dos diócesis por las cuestiones patrimoniales, el entonces nuncio en España, Mons. Lajos Kada, nombró una «Comisión de expertos canonistas para el estudio de los problemas que afectan a la propiedad y trasmisión de bienes de las diócesis de Lérida y Barbastro-Monzón». Esta Comisión de canonistas, que presentó su informe ante el nuncio el 1 de diciembre de 1997, estableció entre sus Principios que se determinaba acudir, para el estudio de las operaciones patrimoniales, al Código de Derecho Canónico de 1917, y no el Código vigente en la actualidad, que data de 1983. Argumentó la Comisión que el CIC de 1917 — que suponía la sistematización de las Decretales que habían regido hasta esa fecha las actuaciones eclesiásticas- servía tanto para la época de formación del Museo del Seminario ilerdense como para la época posterior de desarrollo de este, a lo largo de buena parte del siglo $\mathrm{XX}^{14}$.

A la vista del informe de esta Comisión, la Nunciatura Apostólica, el 29 de junio de 1998, emitió un Decreto decidiendo la titularidad

«...el patrimonio artístico procedente de las parroquias desmembradas, y que se encuentra actualmente en Lleida, está a título de depósito y no de propiedad, mientras la diócesis de Lleida no pruebe lo contrario en cada caso; por lo que, de ser reclamado por sus legítimos propietarios, debe devolverse...»

Las posiciones continuaron enfrentadas ya que desde Lérida se esgrimía el derecho de propiedad en virtud de unos documentos conservados en el Archivo

12 Así lo refiere el texto de una carta dirigida por el obispo de Lérida al nuncio apostólico con fecha de 26 de junio de 1995 que aparece citado en el Decreto de la Signatura Apostólica de 23 de abril de 2001, véase AZNAR GIL, F. R. y ROMÁN SÁNCHEZ, R. (coords.), Los bienes artísticos..., op. cit., pp. 132-133.

${ }^{13}$ La prescripción es la forma de adquirir un derecho subjetivo, como puede ser el dominio o propiedad de bienes, mediante su uso o posesión en la forma y condiciones determinadas por la ley. Este aspecto en relación con los bienes artísticos en disputa fue objeto de estudio de sucesivos decretos canónicos. En ello abunda el Decreto de la Signatura Apostólica de 28 de abril de 2007.

14 «Informe sobre el Contencioso entre las Diócesis de Lérida y Barbastro-Monzón de 1 de diciembre de 1997. Principio 2» en AZNAR GIL, F. y ROMÁN SÁNCHEZ, R. (Coords.), op. cit., p. 117. 
Los bienes de las parroquias altoaragonesas en el Museo de Lérida: de sentencias...

Diocesano de Lérida. Este obispado elevó a los tribunales eclesiásticos una serie de recursos que sucesivamente fueron rechazados por los órganos competentes.

Entre tanto se pondría en marcha el proceso de ejecución del Decreto del nuncio, es decir, los mecanismos para determinar cuáles de los bienes reclamados por Barbastro-Monzón habían de ser devueltos a sus parroquias. La primera fase del proceso de ejecución de este Decreto de la Nunciatura, de 29 de junio de 1998, la constituye la creación de la Comisión de reparto de bienes ${ }^{15}$ pero, ante el fracaso de esta vía, se buscaría una nueva forma jurídica de ejecución: el nombramiento, por parte del nuncio apostólico, de un Mediador con plenos poderes para la ejecución del citado Decreto.

En la segunda fase del proceso de ejecución, el Mediador o Ejecutor, atendiendo a que la diócesis de Lérida no es propietaria de las piezas por compra-venta $^{16}$ y a que no puede aceptarse la usucapión ni otros medios de adquirir el dominio, concluyó que los bienes del patrimonio histórico-artístico se hallaban en Lérida a título de depósito — como ya había establecido el Decreto de la Nunciatura Apostólica de 29 de junio de 1998-. Añadiendo que

«...dichos bienes fueron cedidos por las parroquias, legítimas propietarias de los mismos, de forma que no resultaran perjudicadas ni en su propiedad o dominio, ni en su uso o posesión; es decir, que fueron entregadas en depósito, que tiene la virtualidad de que el usufructuario debe devolver el bien cedido cuando los reclame el legítimo propietario. El depósito no constituye un título justo, hábil, ni legítimo para transmitir el dominio, ni para adquirirlo por prescripción (por mucho que sea el tiempo que transcurra) y no permite por ello la adquisición dominical por el transcurso de tiempo señalado por la Ley...» 17

Un nuevo Decreto de la Congregación para los obispos, de 8 de septiembre de 2005, fue concluyente: primero, porque definió que la propiedad era cosa juzgada según el Decreto de 29 de junio de 1998 y, segundo, porque aceptó la propuesta del Mediador y en su virtud ordenó la devolución de 113 piezas identificadas, en un plazo de un mes, a la diócesis de Barbastro-Monzón. Determinaba además que pertenecen también a las parroquias aragonesas 12 ob-

15 Era esta una comisión paritaria, formada por miembros de las dos diócesis. Se reunió en siete ocasiones desde su constitución el 17 de septiembre de 2001. En la práctica esta Comisión consiguió unos primeros acuerdos en el reparto de las piezas, pero pronto su labor quedaría bloqueada, siendo finalmente suprimida por Decreto de la Nunciatura de 7 de julio de 2004.

${ }_{16}$ El Mediador se apoyó, para dirimir la situación de los objetos que reclamaba Barbastro, en el principio fundamental de que ni obispo ni párrocos son los dueños de los bienes de sus diócesis o parroquias y que administran bienes ajenos, que cualquier tipo de transacción con los bienes eclesiásticos — sobre todo si se trata de bienes preciosos - no puede realizarse sin un permiso especial de Roma. Y que el obispo no puede autorizar donaciones de bienes de las parroquias, salvo por limitadas justas causas y en todo caso cumpliendo los requisitos correspondientes. Lérida contradijo siempre este principio alegando que las piezas habían sido adquiridas por el obispo Meseguer y que el obispado de Lérida las ha detentado como propiedad de manera pública, pacífica e ininterrumpida.

17 «Anexo al Decreto de la Congregación para los Obispos, 8 de setiembre de 2005» en AZNAR GIL, F. y ROMÁN SÁNCHEZ, R., (coords.), op. cit., p. 196. 
jetos que en la actualidad se consideran desaparecidos. Y que, al no haber sido probada la procedencia de 15 de los objetos reclamados, estos debían permanecer en Lérida.

En septiembre de 2007 se emitía el Decreto definitivo de la Signatura Apostólica que, entre otras cuestiones, reincidía en dos aspectos fundamentales: primero, que las parroquias son las propietarias legítimas de los bienes reclamados por la diócesis de Barbastro-Monzón y, segundo, que, a pesar de las interferencias habidas desde algunos ámbitos políticos y civiles, los órganos eclesiásticos son los únicos capacitados para dirimir el litigio.

Y el 30 de junio de 2008, los entonces representantes de las dos diócesis firmaron en presencia del nuncio un acuerdo para dar cumplimiento al Decreto de la Congregación para los obispos de 8 de septiembre de 2005. En dicho compromiso el entonces administrador apostólico de Lérida acataba este Decreto y manifestaba su propósito de entregar los bienes histórico-artísticos dentro de los treinta días siguientes.

Dos años más tarde, estando las piezas todavía en el Museo de Lérida y ante la inminencia de la visita del papa a España, el 27 de octubre de 2010, los obispos volvieron a reunirse, sellando un nuevo acuerdo que reafirmaba el anterior. De nuevo los prelados volvían a reconocer el carácter eclesiástico de las piezas y la propiedad por parte de las parroquias transferidas, y acordaban cooperar en el estudio, conservación y recuperación de los bienes. Así mismo

\footnotetext{
«...las dos diócesis se comprometen a remover los obstáculos jurídicos que se presenten para su devolución, considerando la naturaleza jurídica de dichos bienes...» ${ }^{18}$
}

\subsection{Acciones paralelas}

En la actualidad las piezas de las parroquias de la diócesis de BarbastroMonzón continúan en el MLDC porque una serie de acciones al margen del Derecho canónico obstaculizan la posibilidad de su regreso a tierras aragonesas.

Ante la contundencia del Decreto de 1998, Lérida emprendió varias gestiones con objeto de justificar una pretendida «unidad de la colección museística», uno de los argumentos que desde la Generalitat de Catalunya se han esgrimido reiteradamente para impedir el cumplimiento de las sentencias canónicas. Sobre el aspecto de la unidad museística se incidirá más tarde.

18 Citado en HUGUET, Á., «El obispado de Barbastro-Monzón se opone al recurso de los Amics del Museu» en El Cruzado Aragonés, 19 de noviembre de 2010, p. 2. 
Los bienes de las parroquias altoaragonesas en el Museo de Lérida: de sentencias...

Una de estas acciones, de vital importancia para entender la situación actual, fue la constitución el día 27 de mayo de 1999 del Consorcio del MLDC ${ }^{19}$. Forman parte de esta institución el Obispado ilerdense, el Ayuntamiento de Lérida, la Diputación Provincial, la Generalitat de Catalunya y la Comarca del Segriá. En dicho Consorcio la propiedad de las obras de arte sigue perteneciendo a cada una de las instituciones que la integran, pero la gestión corresponde al Consorcio, que funciona de acuerdo con unos Estatutos propios ${ }^{20}$. El obispado de Lérida adscribió a esta agrupación, en 1999, los fondos museísticos de la diócesis entre los cuales figuran los bienes que, por Decreto de la Nunciatura de 29 de junio de 1998, pertenecen a las parroquias aragonesas.

Por su parte, los gobiernos aragonés y catalán emprendían, en la primavera de ese año, las acciones necesarias para incluir en sus respectivos catálogos de Patrimonio Cultural las obras en litigio, aunque el primero de ellos no concluyó este trámite ${ }^{21}$ que fue retomado en 2010.

El 20 de mayo de 1999 la Conselleria de Cultura de la Generalitat incluyó en el Catálogo del Patrimonio Cultural Catalán la colección del MLDC formada por 1810 objetos. Estos objetos se catalogaron como colección atendiendo a los valores culturales de la agrupación de bienes como tal.

El Gobierno de Aragón, por su parte, tras realizar un estudio detallado de cada uno de los bienes reclamados por la diócesis de Barbastro-Monzón con el fin de determinar el nivel de protección preciso para cada uno de ellos, por resolución de la Dirección General de Patrimonio Cultural, de 3 de noviembre de 2010, incoaba el expediente de declaración de 24 de las piezas en litigio como Bienes de Interés Cultural y, en la misma fecha, se iniciaban los trámites para incluir 86 bienes más en el Inventario de Patrimonio Cultural Aragonés. A principios de ese año el Frontal de Berbegal también había sido declarado BIC por este Ejecutivo.

La catalogación somete los bienes a un régimen estricto de protección que los supedita a intervención administrativa, aunque no prejuzga su propiedad. El eje-

19 El acto de constitución del Consorcio se celebró en la iglesia de San Martín de Lérida el 27 de mayo de 1999 presidido por el entonces Consejero de Cultura de la Generalitat, dando así cumplimiento a un acuerdo aprobado el 18 de mayo de de 1999. Véase «Cataluña insiste en la unidad de las obras durante la creación del Consorcio del Museo Diocesano» en Diario del Alto Aragón, Huesca, 28 de mayo de 1999 , p. 7.

Según fuentes catalanas, los trámites para la creación del Consorcio se iniciaron en 1988. Véase BERLABÉ JOVÉ, C., «El Museo Diocesano de Lérida. Historia y vicisitudes» en Artigrama, núm. 20, Departamento de Historia del Arte, Universidad de Zaragoza, 2005, p. 39.

20 El obispado de Lérida solo tiene un representante en el Consorcio y carece de la facultad de veto. Las decisiones en el Consorcio se adoptan por mayoría simple o mayoría de dos tercios, según los casos, lo que de facto significa una posición de inferioridad en los procesos de toma de decisiones por parte del obispado.

${ }_{21}$ Una resolución de la Consejería de Cultura del Gobierno de Aragón, de 19 de noviembre de 2010, ordenó archivar el expediente incoado mediante la resolución de 29 de abril de 1999, por la que se había iniciado expediente para incluir en el Inventario del Patrimonio Cultural Aragonés 119 obras de arte pertenecientes a parroquias aragonesas de la diócesis de Barbastro-Monzón. Véase BOA (Boletín Oficial de Aragón), Núm. 253, de 29 de diciembre de 2010, pp. 29669-29670. 
cutivo aragonés no recurrió en 1999 la catalogación de los bienes hecha desde la Generalitat, lo que le valió las críticas por parte de los partidos aragoneses en la oposición.

Pero volviendo a las actuaciones por parte de Cataluña, en el año 2001 la asesoría jurídica del Departament de Cultura de la Generalitat solicitó a varios juristas catalanes de prestigio sus opiniones sobre la capacidad de dicho gobierno para ejercer alguna acción jurídica civil que pudiera evitar la entrega de las piezas en el momento de que las parroquias exigieran su devolución y hubiese que efectuar el traslado. El llamado «Informe Pintó» contestó negativamente a todas las cuestiones planteadas por la Generalitat, aclarando, en primer lugar, que se trataba de un asunto estrictamente eclesiástico y que no se podía aplicar la usucapión puesto que

«...Bajo el punto de vista del Derecho privado, o de análisis de los derechos subjetivos de la Diócesis de Lérida y también del Consorcio allí radicado, y de las distintas parroquias — personas jurídicas eclesiásticas_ radicadas en la Comunidad Autónoma de Aragón, no hay duda de que no ha existido transferencia alguna dominical de las parroquias ni a la diócesis, ni al Museo ni al Consorcio, y en consecuencia, tienen aquellas el derecho de reivindicar el indicado dominio e instar la restitución $[\ldots]$

Bajo el punto de vista del Derecho privado, no es posible el ejercicio de ninguna acción ante la jurisdicción civil al objeto de impedir el derecho de las parroquias propietarias a pedir el retorno de los bienes que son suyos... $\gg^{22}$

A pesar de ello se abriría, como veremos, la vía jurídica civil.

El obispo de Lérida solicitaba al Gobierno catalán, el 14 octubre de 2005, la autorización para disponer de las piezas de Barbastro-Monzón cuya devolución había ordenado un mes antes el Decreto de la Congregación para los obispos.

Como asesoramiento sobre la cuestión, la Conselleria de Cultura encargó un estudio al Instituto de Estudios Catalanes (IEC). La Sección Histórico-Arqueológica de dicho Instituto emitió, en noviembre de 2005 — dos meses después del Decreto de la Congregación para los obispos-, un informe que contrariaba cualquier acción que supusiera la devolución de los bienes a las parroquias aragonesas o de su gestión conjunta por parte de las dos comunidades. Aducían los técnicos del IEC que las piezas pertenecían al patrimonio histórico y cultural catalán, de manera que no hallaban argumentos éticos ni legales que aconsejaran su devolución al obispado de Barbastro-Monzón. Insistía este informe en que dichos bienes debían permanecer en el MLDC, al que se concebía, en su conjunto, como instrumento para entender la historia y la identidad del antiguo territorio episcopal, que la dis-

22 PINTÓ RUIZ, J. J., Dictamen sobre els béns del Museu de Lleida procedents de les parròquies de la Franja, de septiembre de 2001. Texto original en catalán. 
Los bienes de las parroquias altoaragonesas en el Museo de Lérida: de sentencias...

persión de sus colecciones perjudicaba al conjunto y que la unidad de la colección diocesana era irrenunciable, señalando además que, de disgregarse, sentaría un negativo precedente para otros museos catalanes. Concluían los técnicos que

«...el valor del conjunto de la colección es absolutamente superior al de la suma de cada uno de los objetos que la integran...»23

Un Informe de la Asociación de Museólogos de Cataluña de 22 de febrero de 2006 señala que no existe ningún razonamiento museológico que justifique la descatalogación de la colección del Museo de Lleida y la desmembración de una parte de su colección y se reafirma

«...en el principio de permanencia e integridad de las colecciones, siguiendo las recomendaciones internacionales que se derivan del código de deontología del Consejo Internacional de Museos (ICOM)...»

La Conselleria de Cultura de la Generalitat, por Resolución de 6 de abril de 2006 (conocida como Resolución Mieras, por el nombre de la entonces titular), acordó estimar parcialmente la petición del obispado de Lérida y lo autorizó a disponer de determinados bienes muebles que forman la colección del MLDC, bajo la condición de que se cumplieran una serie de medidas que garantizasen la unidad y la integridad de la colección. Pero la citada resolución no contentó ni a catalanes ni a aragoneses.

Los argumentos de gestión conjunta que proponía la Resolución Mieras contrariaban las radicales premisas del citado Informe del IEC. Según recogía la prensa de la comunidad catalana, la Conselleria presionó al Instituto y su presidente moderó el informe original de los técnicos ${ }^{24}$.

En Aragón no se aceptaron las condiciones impuestas por Mieras ya que, según se vio desde las instituciones aragonesas, el interés perseguido por esta resolución -y por la de declaración de los bienes como parte del Patrimonio artístico de Cataluña en 1999- era la de lograr un bloqueo de los mismos en territorio catalán y bajo la dependencia administrativa de la Generalitat. Esta proponía la gestión unitaria de la colección por un órgano de carácter ejecutivo y decisorio constituido por diversas instituciones de las dos comunidades.

23 Informe de la Sección Histórico-Arqueológica del Instituto de Estudios Catalanes, sobre los objetos del Museo de Lérida Diocesano y Comarcal procedentes de la «Franja de Ponent» que reclama el Obispado de Barbastro-Monzón, Barcelona, 1 de diciembre de 2005. [En línea] http://www.iec.cat/butlleti/75/cronica/cronica_seccioHA.html [consulta 20 de junio de 2010]

Cabe señalar que la expresión Franja de Ponent es la acepción que en Cataluña se utiliza para nominar a unas comarcas, la parte oriental de las provincias de Huesca y Zaragoza, que están dentro del territorio aragonés y que poseen unas singularidades y una riqueza lingüística específicas.

24 «Pressions de Mieras a l'IEC per un estudi de l'art sacre. La consellera de Cultura hauria volgut silenciar un informe contrari al trasllat», publicado en Diari Avui, Barcelona, 4 de abril de 2006, p. 32. 
Contra la Resolución Mieras se plantearon recursos desde el obispado y la Diputación de Lérida que fueron desestimados por el Tribunal Superior de Justicia de Cataluña. La Sala de lo Contencioso-Administrativo del Tribunal Supremo falló negativamente, en agosto de 2010, el último recurso interpuesto para anularla.

Lo que se ha dado en llamar el «blindaje de la colección» ${ }^{25}$ se consumaría en el Parlament de Catalunya con la aceptación de una moción, de 19 de mayo de 2006, que limitaba la autorización del traslado de piezas al cumplimiento de la Resolución Mieras y acordaba que las obras se conservarían y expondrían en el MLDC mientras no se llegase a un acuerdo de gestión consensuada por las partes en litigio ${ }^{26}$.

\section{En opinión del doctor en Derecho Carlos López Bravo, la Resolución Mieras}

«...se excedió al declarar como perteneciente al Patrimonio Cultural de Cataluña la colección del MLDC [...] fue un exceso competencial haber incluido 113 bienes en la declaración de la colección que no eran propiedad del Museo - se encontraban en el mismo a título de depósito-, y que, en segundo lugar, al ser propiedad de parroquias aragonesas pertenecen al patrimonio cultural aragonés. $[\ldots]$

No está justificado ni es legítimo que se impida la devolución de los bienes reclamados a la diócesis de Barbastro-Monzón, por cuanto una figura de protección del patrimonio cultural otorgada mediante acto administrativo debe respetar en todo caso el contenido del derecho de propiedad de los bienes, que sólo en concepto de depósito tutela la sede del Museo de Lleida»27

Lérida siguió buscando apoyos para su argumentación de la propiedad de las obras. En 2009 el profesor de Derecho Civil José Castañeda realizó un informe en el que afirmaba que los bienes en litigio son propiedad del obispado de Lérida por la transmisión de las piezas por compraventa, permuta o donación o, llegado el caso, por usucapión ${ }^{28}$. Partía Castañeda de la premisa de que la normativa aplicable para dilucidar la propiedad de las piezas es el Código Civil, arguyendo que el único cuerpo legislativo existente en 1893 — cuando comenzaron a entrar

25 «El Parlamento catalán blinda el arte sacro de la franja para no devolverlo» en $A B C$, Madrid, 20 de mayo de 2005, p. 57.

${ }_{26}$ «Moción 57/VII del Parlamento de Cataluña, sobre el contencioso relativo al patrimonio artístico del Museo de Lérida Diocesano y Comarcal» en Boletín Oficial del Parlamento de Cataluña, núm. 338, 22 de mayo de 2006, p. 7.

${ }_{27}$ LÓPEZ BRAVO, C., Informe sobre la situación jurídica de los Bienes Culturales del obispado de Barbastro-Monzón, propiedad de parroquias aragonesas, incluidos en el Catalogo del Patrimonio Cultural catalán, como integrantes de la colección del Museo de Lleida, Diocesano y Comarcal, Sevilla, 15 de enero de 2010. El informe fue solicitado en interés del obispado de Barbastro-Monzón.

${ }^{28}$ En los mismos términos se desenvuelve la tesis doctoral de la actual conservadora del MLDC. Véase BERLABÉ JOVE, C., El Museu de Diocesà de Lleida. La seva formació i la legitimitat del seu patrimoni artístic, tesis doctoral, vol. I, pp. 75 y 120-121. [En línea] http://www.tesisenxarxa.net/TDX-0928110165936/index.html [Consulta 29 de octubre de 2010] 
Los bienes de las parroquias altoaragonesas en el Museo de Lérida: de sentencias...

las pielzas en el Museo del Seminario de Lérida- era esta normativa ${ }^{29}$. Premisa a todas luces contraria al principio referido más arriba de la vigencia de las Decretales y su posterior codificación en 1917, considerado por la Comisión de expertos canonistas.

A raíz del acuerdo de los obispos del 27 de octubre de 2010, la Generalitat de Catalunya, por medio de un comunicado de su Departament de Cultura, se pronunciaba sobre dicho acuerdo manifestando que la colección de obras de arte del MLDC está amparada por la Ley catalana de Patrimonio Cultural y por las sucesivas resoluciones del parlamento catalán y reiterando, además, su voluntad de encontrar una solución dialogada sobre la base de las condiciones que siempre interpusieron: la legitimidad y la unidad de la colección, así como por la legislación catalana en materia de patrimonio cultural ${ }^{30}$. Pocos días más tarde, los juzgados de Lérida desestimaron la petición del actual obispo ilerdense que, siguiendo las indicaciones del nuncio, solicitó a la justicia civil el permiso para entregar las obras a BarbastroMonzón. La providencia de la juez, de 8 de noviembre, expresaba que no podía autorizar ningún traslado y que es la Iglesia la que debe forzarlo.

\subsection{El litigio ante la justicia civil}

La Asociación de Amigos del Museo de Lérida solicitó a la justicia civil que se pronunciase sobre la propiedad de 83 de las obras que reclama el obispado de Barbastro-Monzón. La asociación argumentó la propiedad por parte de Lérida, de nuevo, en el derecho de la usucapión. Los tribunales de Lérida desestimaron la demanda el 7 de septiembre de 2010. Dicha sentencia reconocía, una vez más, que las parroquias mantienen su derecho de propiedad y que la Iglesia se rige en España por el Derecho Canónico y no por el Derecho Civil ni por el Derecho foral de Cataluña. En cuanto al argumento de la usucapión, el tribunal de Lérida estimó que ese obispado no poseyó los bienes en concepto de dueño sino de depositario. Este veredicto sería recurrido una semana después por los Amigos del Museo.

El 31 de mayo de 2010 se daba a conocer la sentencia del Juzgado de 1른 $^{\text {Ins- }}$ tancia de Barbastro que denegaba el procedimiento del exequatur. Un año antes, el obispado de Barbastro-Monzón y el gobierno aragonés habían solicitado este procedimiento, es decir, la intervención de la jurisdicción ordinaria para ejecutar la devolución de los bienes de las parroquias, como posibilidad para acelerar el

29 CASTAÑEDA, J. E., Respecto al litigio que mantienen el obispado de Lleida y el de BarbastroMonzón acerca del patrimonio artístico, Madrid, 8 de julio de 2009. [En línea] http://www.amicsmuseuIleida.org/pages/10-sortida-ruta-dels-templers.html [consulta 30 de noviembre de 2010]. El informe fue solicitado por la Asociación de Amigos del Museo de Lérida.

30 Comunicado del Departamento de Cultura y Medios de Comunicación. Emitido en relación al «litigio del arte sacro", 28 de octubre de 2010.

[En línea] http://www20.gencat.cat/portal/site/CulturaDepartament/menuitem [Consulta 20 de noviembre de 2010] Texto original en catalán. 
cumplimiento de las sentencias eclesiásticas. Contra la concesión del exequatur se personaron la Asociación de Amigos del Museo y el Consorcio que gestiona el MLDC. De nuevo la justicia civil consideró que la competencia para resolver el litigio es de los tribunales eclesiásticos, cuyos veredictos reiteraron la propiedad de las parroquias. Y que las autoridades eclesiásticas competentes gozan de la capacidad de llevar a cabo la sentencia y, asimismo, que «...pueden ejecutar estas resoluciones conforme a las vías que les son propias, e incluso sancionar a los infractores... »11 El Gobierno de Aragón y el letrado del obispado aragonés presentaron recursos de apelación contra este auto del cual, días antes, el fiscal también había solicitado la revocación.

La vía jurídica penal fue la utilizada por los representantes de los ayuntamientos de Berbegal y Peralta de Alcofea que, en marzo de 2010 interpusieron en el Juzgado de Huesca sendas querellas criminales contra el obispo de Lérida por un presunto delito de apropiación indebida por la retención de las piezas propiedad de las parroquias de Berbegal, Peralta de Alcofea y El Tormillo que están en situación de depósito — reconocido por el obispado ilerdense ${ }^{32}$ - en el MLDC. Dos meses antes el obispo de Huesca había solicitado por escrito a su homólogo de Lérida la devolución del patrimonio de estas parroquias ${ }^{33}$.

Pero la vía eclesiástica se había considerado mucho antes ${ }^{34}$. En el ayuntamiento y en la parroquia de Berbegal, se conservan las copias de la correspondencia entre Javier Osés, entonces obispo de Huesca, y el de Lérida durante la pri-

${ }^{31}$ Fragmento de la sentencia emitida por el Juez de Barbastro. Citado en AZNAR GIL, F. R. y ROMÁN SÁNCHEZ, R., "La iglesia frente a sus responsabilidades» en Heraldo de Aragón, Zaragoza, 10 de junio de 2010, p. 23.

Véase también «El juez dice que el decreto del Vaticano del arte no tiene efectos legales en España» en La Mañana, Lérida, 2 de junio de 2010 y «El juez deniega el exequátur y recuerda la validez de las sentencias eclesiásticas» en Diario del Alto Aragón, 2 de junio de 2010, Huesca, pp. 2 y 3 . Se han recogido deliberadamente estos dos titulares de la prensa de las dos provincias para dejar constancia de las diferentes lecturas que se hace de un mismo texto jurídico.

32 «Delito de apropiación indebida», en Diario del Alto Aragón, Huesca, 16 de noviembre de 2010, p. 9. La noticia refiere la existencia de una carta oficial del 27 de diciembre de 2005 , dirigida a la abogada de la Asesoría Jurídica del Departament de Cultura de la Generalitat de Catalunya por el entonces abogado de la diócesis de Lérida.

En dicha carta se especifica que «...estas obras de arte están en el Museo bajo título de depósito debidamente documentado...» Advierte además el letrado de la diócesis que las personas físicas o jurídicas propietarias de las piezas —entre las que se cita expresamente a las parroquias de Berbegal y $\mathrm{Pe}$ ralta de Alcofea- «...en caso de que se disolviera la colección catalogada tendrían derecho a reclamar la devolución de las piezas, y, en consecuencia, la administración del Museo tendría que devolverlas a sus propietarios ...»

${ }_{33}$ «La diócesis de Huesca hace efectiva la declaración de su patrimonio» en Diario del Alto Aragón, Huesca, 23 de enero de 2010, p. 7.

34 NAVAL MAS, A., «El Frontal de Berbegal, así no» en Diario del Alto Aragón, Huesca, 13 de julio de 2005, p. 18. En este artículo de opinión, el profesor Naval refería que en su día, el obispo de Huesca había iniciado los trámites consultando con el entonces nuncio, Mons. Lajos Kada, y con el obispo de Lérida. El nuncio había dado una respuesta verbal, sugiriendo esperar a que terminara el litigio entre Lérida y Barbastro-Monzón para reclamar las piezas de Huesca. La respuesta desde Lérida, según afirma Naval en ese artículo, fue entonces escrita, «...constituyendo su contestación un documento fundamental para la recuperación de la pieza...». 
mavera de 1997. El párroco y varios miembros del ayuntamiento habían mantenido previamente conversaciones con el prelado oscense.

\author{
El Obispo de Fuesca
}

Reg.S.17/97

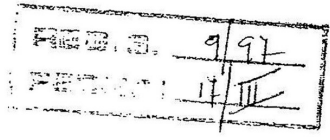

Excmo. y Rvdmo. Sr.:

Desde la responsabilidad que la Iglesia de Huesca y su Obispo tiene ante la iglesia local, la sociedad y las futuras generaciones de conservar y transmitir íntegro el patrimonio vinculado a las parroquias y comunidades cristianas.

A la visita de la sensibilidad social que se ha creado en torno al Patrimonio Artístico vinculado a las parroquias aragonesas que fueron de la diócesis de Lérida.

$Y$ en coherencia con la nueva estructuración del Estado Español, según esquema especialmente propugnado por la comunidad catalana.

Creemos que este es el momento adecuado para revisar aspectos que afectan a la diócesis de Lérida y Huesca relacionados con el Patrimonio Artístico de la parroquias, que, habiendo sido de la administración del Obispo de Lérida, han pasado al de Huesca, y que son:

La gestión llevada acabo en $1.889-1905$ a sugerencia del Excmo. y Rvdmo. Sr. Messeguer, Obispo de Lérida, en relación con el desmontaje y traslado a la Sede Episcopal de esa Diócesis de la portada de la Iglesia del Tormillo, dejando en abandono esta noble y destacada construcción del siglo XIII, que finalmente se hundió por este abandono.

En el traslado a la sede de Lérida de dicha portada, acompañaron a ésta un capitel y cinco fragmentos de arquivolta, de esta misma iglesia.

Igualmente, en el Pontificado del Excma. y Rvdmo. Sr. Messeguer, fue trasladado al mismo lugar el frontal del siglo XIII, de la parroquia ex- culegiata de Santa María la Blanca de Berbegal, sin que en ningún momento haya habido en la localidad conciencia colectiva de que fuera vendido, regalado o permutado por algún otro bien, servicio, o mejora, sino, por el contrario, quedando constancia, desde remotas épocas, y permaneciendo el

En la carta remitida por obispo oscense a su homólogo el día 12 de marzo de ese año (figs. 2 y 3), se incidía en que, desde la responsabilidad del ministerio episcopal,

«...es el momento de solicitar formalmente el frontal de la parroquia de Berbegal, la tabla de Peralta de Alcofea, el capitel y los cinco fragmentos de arquivolta de la parroquia de El Tormillo, esperando que la diócesis de Lérida y su Obispo, desde el entendimiento que debe regir las relaciones entre las comunidades cristianas, y al margen de impropias preocupaciones por retener bienes y mantener cotas de prestigio, acceda fraternalmente al traslado, en breve, de estas piezas...» 


\begin{abstract}
sentimiento entre la feligresía de haber sido trasladado sin otro acuerdo que la decisión del Obispo.

El mismo sentimiento permanece en la localidad de Peralta de Alcofea en relación con una tabla del siglo XV con la iconografía tradicional de San Pablo.
\end{abstract}

Esta Diócesis y la parroquia de Berbegal, manifiesta su reconocimiento por los trabajos de restauración y la conservación mantenida del frontal, y en este caso, el cumplimiento de la obligación por parte de la Administración de la diócesis de Lérida de velar por el patrimonio acumulado por la generosidad, muchas veces, sacrificio, y, siempre, devoción de los fieles.

Consecuentemente, tras la reiteración con que, desde hace algún tiempo, vienen dirigiéndose a nosotros para reclamar este patrimonio, $y$, no sin considerar con tristeza la dificultad que comporta la recuperación de la portada de la iglesia del Tormillo, pensamos que, desde la responsabilidad que lleva el ejercicio del ministerio episcopal, este es el momento de solicitar formalmente el frontal de la parroguia de Berbegal, la tabla de Peralta de Alcofea, el capitel y los cinco fragmentos de arquivolta de la parroquia del Tormillo esperando que la Diócesis de Lérida y su Obispo, desde el entendimiento que debe regir las relaciones entre las comunidades cristianas, y al margen de impropias preocupaciones por retener bienes y mantener cotas de prestigio, acceda fraternalmente al traslado, en breve, de estas piezas.

Huesca a 12 de Marzo de 1997

EXCMO Y RVDMO. SR. OBISPO DE LA DIOCESIS DE LERIDA

Figs. 2 y 3. Reproducción de la carta enviada por el obispo de Huesca a su homólogo de Lérida el 12 de marzo de 1997, reclamando las piezas de las parroquias de Berbegal, Peralta de Alcofea y El

Tormillo.

La contestación desde el obispado de Lérida data del 2 de abril siguiente. En ella Malla se limitaba a mostrar su extrañeza y, no obstante, su comprensión ante la petición de Huesca.

En el momento de escribir estas páginas, los pleitos judiciales citados en este epígrafe quedan pendientes de resolución por los recursos planteados para cada uno de ellos. 
Los bienes de las parroquias altoaragonesas en el Museo de Lérida: de sentencias...

\section{PIEZAS DE ARTE SACRO DE PROCEDENCIA ALTOARAGONESA EN LÉRIDA}

\subsection{Los bienes ${ }^{35}$ de la diócesis de Barbastro-Monzón}

Como se ha explicado más arriba, el Decreto de la Congregación para los Obispos, de 8 de septiembre de 2005, ratificado por el Decreto de la Signatura Apostólica de 28 de abril de 2007, concretó los bienes artísticos que habían de ser restituidos por parte de la diócesis de Lérida a la de Barbastro-Monzón. Se estableció que han de ser devueltos 113 bienes de arte sacro, a los que han de añadirse otros 9 que fueron en su día identificados por la Comisión de expertos designada por la Nunciatura. Del total de estos 122 bienes a entregar a Barbastro-Monzón se dan hoy por desaparecidos 12 de ellos que, en caso de ser hallados, deberán agregarse a esta nómina ${ }^{36}$.

El hecho de que la sentencia actual solo contemple estos bienes no impide que se puedan producir nuevas reclamaciones por parte de la diócesis aragonesa en función de nuevas investigaciones, ya que durante el litigio canónico se dirimió solo sobre la propiedad de las piezas de las cuales este obispado pudo demostrar la parroquia de origen.

De los bienes que hasta el momento están pendientes de devolución, no llegan a cuarenta los que tienen un alto interés museístico: diecisiete de ellos pueden contemplarse en las salas del MLDC ${ }^{37}$ y otros tres están expuestos al culto ${ }^{38}$ en la iglesia de San Lorenzo, en la capital leridana. Entre los restantes bienes dignos de exponerse en un Museo que actualmente se hallan en la reserva del MLDC se encuentra un variado grupo de piezas entre las que se debe destacar una parte de la indumentaria litúrgica procedente de la ex catedral de Roda de Isábena ${ }^{39}$, además de algunas piezas escultóricas, de pintura y de orfebrería.

35 Se considera bien a un conjunto de piezas determinado. En ocasiones un bien consta de una sola pieza y en otras son diferentes los elementos - varios candelabros, o la predela y el retablo de un altar, o un cáliz con su patena y su cucharita, por ejemplo- que componen un conjunto de uso litúrgico o de ornato eclesiástico.

36 BOA, Núm., 232 de 26 de noviembre de 2010, pp. 27228-27229.

37 Los diecisiete bienes que se exponen en las salas del MLDC son: el Cuenco de Benavente, la Tabla del Nacimiento y Epifanía de Binaced, la Arqueta y el Frontal de San Hilario procedentes de Buira, la Crismera de Castillonroy, el Santo clérigo y la Cruz procesional de Iscles, la Tabla de San Martín de Lascuarre, la Predela con escenas hagiográficas y el Retablo de San Antonio Abad ambos procedentes de Monzón, el Altarcito de Portaspana (constituido por un retablo y una predela), el Retablo de San Cristóbal de Santaliestra, el Calvario de Tamarite, el Frontal de San Vicente de Treserra, el Lienzo de San Pedro de Valcarca, así como dos piezas procedentes de Zaidín: la Predela de Santa Lucía y San Bernardino y la Tabla de San Juan Bautista. El arco cronológico de estos objetos abarca desde finales del siglo XII hasta el siglo XVII.

${ }^{38}$ Expuestos al culto se hallan la Tabla de San Blas de Algayón y dos piezas escultóricas: el San Miguel y la Virgen María, ambas de Zaidín.

39 Entre las piezas de indumentaria procedentes de Aragón cabe destacar el grupo procedente de la ex catedral de Roda de Isábena, del cual las capas pluviales — sobre todo la de San Pedro- y las dalmáticas son piezas muy interesantes, o tres casullas: la de El Arbol de Jesé, y las de San Ramón y 
El grupo más interesante de los bienes en litigio lo constituye la pintura sobre tabla, en su mayoría obras de los siglos XV y XVI. Valor notabilísimo tiene, por ejemplo, el Calvario de Tamarite ${ }^{40}$, que coronó el retablo de una antigua ermita de esta localidad oscense y fue pintado por el aragonés Pedro García de Benabarre. O el magnífico conjunto de pinturas originarias de la iglesia de Binaced de las que la mejor conservada es la Tabla del Nacimiento y la Epifanía, firmada por el leridano Jaume Ferrer ${ }^{41}$. Excepcionales son, dentro de este grupo, las tablas de San Juan Bautista de Zaidín ${ }^{42}$ y de San Martín de Lascuarre ${ }^{43}$, ambas de la mano de Martín Bernat.

Mención aparte merecen, entre los bienes reclamados por Barbastro-Monzón dos antipendios de época románica, procedentes de dos pequeños núcleos de la Ribagorza oscense: el Frontal de San Martín de Treserra, datado en la segunda mitad del siglo XIII, y el Frontal de San Hilario de Buira (fig. 4), de finales del siglo XII, así como la elaborada Arqueta del siglo XIV, procedente de esta misma población, que pudo usarse como contenedor de reliquias o de documentos.

Entre las piezas escultóricas en depósito destacan la Virgen María de Zaidín, elegante escultura gótica en piedra policromada, y las tallas de Santa Ana de Capella y la Piedad de Ardanué, esta última representante del gótico avanzado y expresión entrañable de un arte popular.

El resto de los bienes procedentes de las parroquias de Barbastro-Monzón lo constituyen objetos de variado valor artístico, si bien algunos de ellos se encuentran muy deteriorados.

Las piezas llegaron, como más adelante se explicará, al entonces Museo del Seminario principalmente desde 1894 hasta 1917; una parte de ellas fue trasladada durante la guerra civil por los agentes republicanos de Patrimonio a Lérida para ser ingresadas en el Museo del Pueblo, y, por último, algunos objetos de uso litúrgico fueron recogidos en épocas posteriores hasta 1975 ya que, por circuns-

San Vicente. Conservan, todavía en buen estado, los bordados, algunos datados en el siglo XIV. El resto de piezas de indumentaria se halla en la actualidad en un estado de conservación deficiente, aunque se puede apreciar en ellas su calidad original.

40 Esta magnífica obra data de la segunda mitad del siglo XV. Es una tabla casi cuadrada que conformó el ático de un retablo. En ella se aprecia un calvario con un Cristo ya muerto y San Juan y la Virgen sedentes. Sus figuras se recortan ante un paisaje en el que se destaca la ciudad amurallada de Jerusalén. El dibujo es excelente y los colores, ahora que la tabla está restaurada, tienen una viveza y limpieza extraordinarias.

41 A la Tabla del Nacimiento acompañan otras dos seccionadas por sus extremos que representan las escenas de la Ascensión y de Pentecostés. Datadas aproximadamente en 1434, el profesor Yarza destacó el interesante tratamiento iconográfico de la escena del Nacimiento. El colorido es espectacular y el dibujo detallista en los tipos y en la personalización de cada uno de los rostros.

42 En la más pura línea de la pintura gótica hispanoflamenca, la realización de esta monumental tabla por parte de Martín Bernat fue datada, gracias a la documentación existente, entre 1493 y 1495 . Perteneció al retablo del altar mayor, hoy desaparecido.

${ }^{43}$ De esta obra opina la profesora Lacarra que, por la iconografía representada, se trataría de San Nicolás de Bari y que procedería de la iglesia de Nachá (también en la provincia de Huesca). Véase LACARRA DUCAY, M" ${ }^{a}$ C., "San Nicolás de Bari de Nachá», en Hágios, La iconografía dels sants ribagorçans, Catálogo de la Exposición, Pont de Suert, Lérida, pp. 70-73. 
tancias de despoblación, quedaban desasistidas las iglesias o las ermitas de muchas localidades de la zona oriental de la provincia de Huesca.

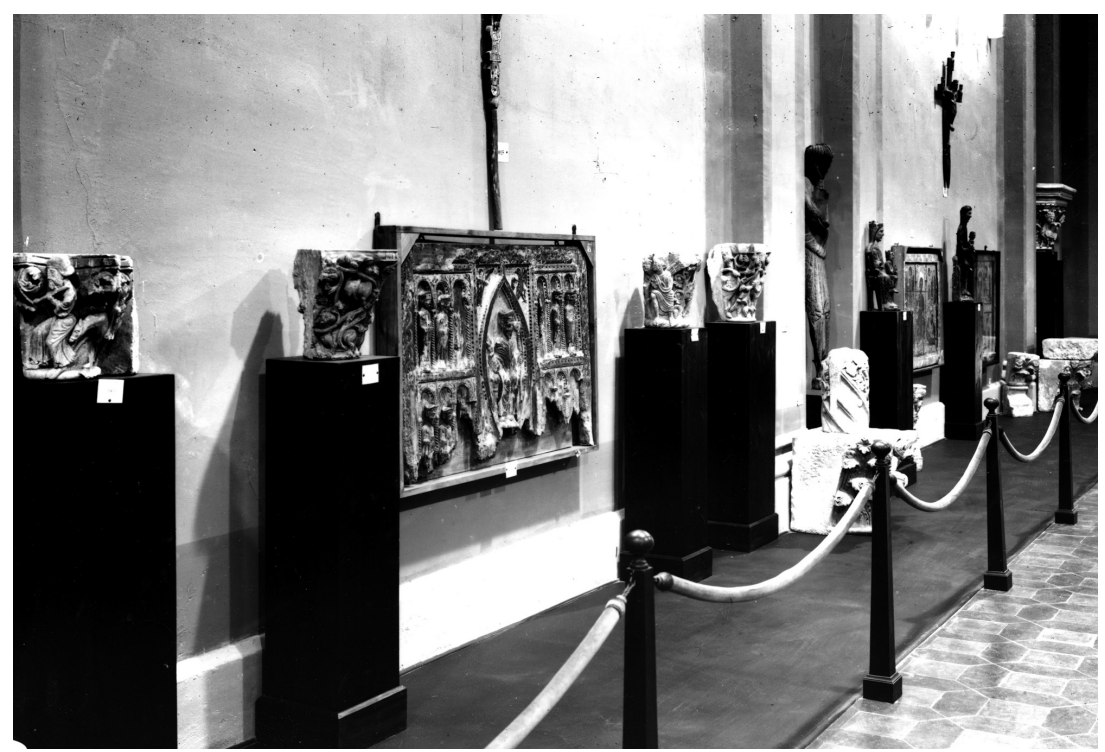

Fig. 4. Aspecto parcial de la sala XIII de la exposición El Arte en España en el Palacio Nacional durante la exposición Internacional de Barcelona en 1929. En primer término, el Frontal de San Hilario de Buira. (Foto Arxiu Fotogràfic de Barcelona, autor desconocido).

Pero si el valor artístico de los bienes en litigio es importante y no escapa ni a los agentes involucrados en él ni a los profanos en arte, la diócesis de BarbastroMonzón considera que todos los bienes - a veces de valor artístico más discreto o incluso nulo- procedentes de las parroquias aragonesas son parte integrante de su patrimonio cultural ${ }^{44}$, ya que tuvieron primordialmente una finalidad evangelizadora: fueron, en muchos casos, fruto de una devoción popular, anónima y sincera, que contribuyó con esfuerzo al ornato de sus templos.

Los aragoneses entienden estas piezas como herencia, como testimonio de unos tiempos en que la religión y las creencias constituyeron una parte importante del acervo cultural de nuestros pueblos. Eran, unas veces, obras de artistas reconocidos en su época, donadas a la Iglesia por patronos generosos, y otras veces, producto de artistas locales anónimos que trabajaron para cofradías o para donantes más modestos y que honraron una fe o, a veces, un fervor popular que resulta un tanto extraño a esta sociedad moderna.

44 IGUACÉN BORAU, D., Diccionario del patrimonio cultural de la Iglesia, Eds. Encuentro, Madrid 1991, p. 697. Por Patrimonio cultural de la Iglesia en España se entiende el conjunto de los bienes inmuebles y objetos muebles de interés artístico, histórico, documental, bibliográfico, arquitectónico, arqueológico, paleontológico y etnográfico, en posesión de la Iglesia Católica en España producidos en ella, a través del tiempo, para el desarrollo del culto divino, el servicio pastoral del pueblo y la organización de la vida comunitaria. 


\subsection{Obras de arte reclamadas por las parroquias de la diócesis de Huesca}

En el MLDC se encuentran en situación de depósito las piezas de las parroquias de Berbegal, El Tormillo y Peralta de Alcofea, que dependieron de la diócesis de Lérida hasta que, en septiembre de 1955, pasaron a la mitra de Huesca ${ }^{45}$.

De estas piezas, la más reconocida es el Frontal de altar del Salvador de Berbegal ${ }^{46}$, fechado por el profesor Borrás Gualís en el primer decenio del siglo XIII, (véase fig. 5). Este frontal está considerado, por su calidad técnica, su singularidad estilística y su belleza, como una de las piezas más excepcionales del arte medieval aragonés. Ocupa un lugar preferencial en la exposición del MLDC.

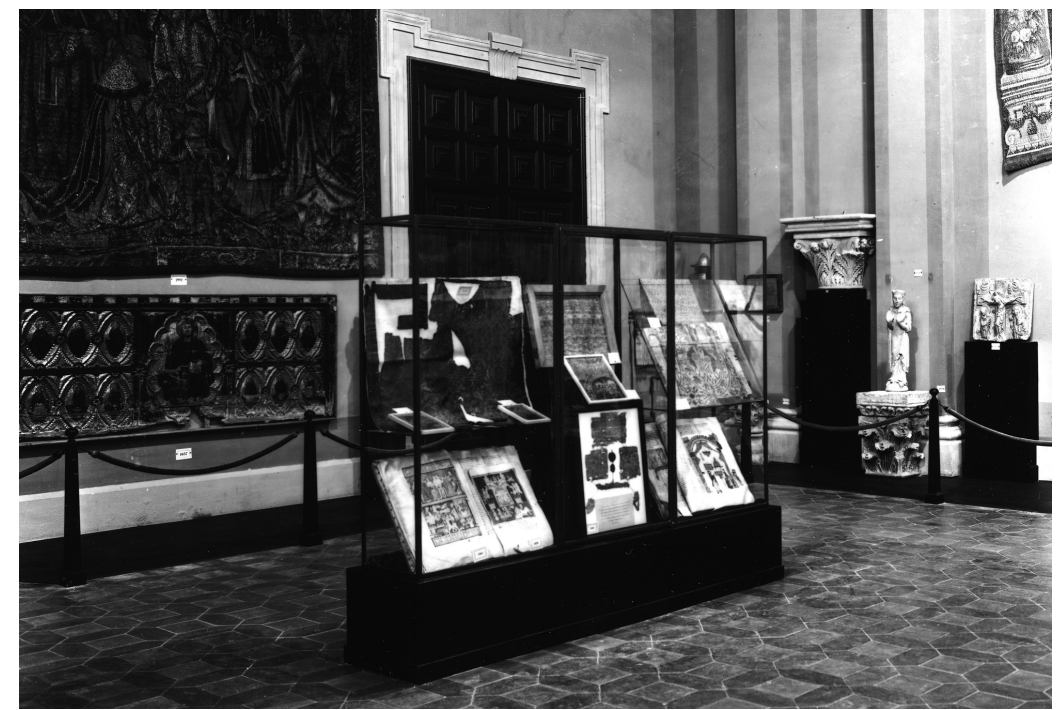

Fig. 5. El Frontal de altar del Salvador de Berbegal, a la izquierda de la imagen, durante la exposición El Arte en España, en Barcelona, 1929. (Foto Arxiu Fotogràfic de Barcelona, autor desconocido).

45 Esta anómala situación de dependencia de Lérida de unas localidades situadas geográficamente en la zona central de la provincia, en las tierras entre los ríos Alcanadre y Cinca, se explica por un complejo proceso que tiene su origen en las luchas territoriales de los obispos durante la Edad Media. Siglos después, en 1571, por el interés de Felipe II en aumentar las sedes episcopales en sus dominios para fortalecer la frontera con Francia, se restaura la mitra barbastrense pese a la oposición de Lérida. Para compensar a los ilerdenses, pasaron a formar parte de su territorio la iglesia de Berbegal — cabeza de arciprestazgo-, entre otras de sus inmediaciones. Véase GROS BITRIA, E., op. cit., pp. 123-127 y 133; CONTE OLIVEROS, J., Viaje por los pueblos oscenses, Siglo XVI. Tomo II. Año 1560, Librería General, Zaragoza, 1980, p. 138.

Estas parroquias, muy alejadas geográficamente de Lérida, estuvieron regentadas por sendos párrocos catalanes desde mediados de los cincuenta hasta los ochenta del siglo pasado. A pesar de su dependencia de la mitra oscense, los dos curas siempre mantuvieron relación con el clero leridano.

46 El Frontal de altar del Salvador es una tabla tallada, dorada y pintada que fue encargada para ocupar el altar mayor de la ex colegiata de Santa María la Blanca en Berbegal. Los expertos destacan en él su gran tamaño - que encaja perfectamente con las proporciones del ábside donde estuvo ubicado-y su elaborada factura. La calidad y el detalle de su dibujo y colorido lo convierten en un objeto único, vinculado con la producción artística del círculo de Sijena. Véase BORRÁS GUALÍS, G., y GARCÍA GUATAS, M., La pintura románica en Aragón, CAI-Fundación Mediterránea, Zaragoza, 1978, pp. 355-364. 
Los bienes de las parroquias altoaragonesas en el Museo de Lérida: de sentencias...

Las obras originarias de Peralta son dos pinturas que hasta principios del siglo $X X$ se conservaron en la iglesia de la localidad, ambas datan de finales del siglo XV: una Tabla de San Pablo y otra de San Pedro y el Calvario ${ }^{47}$. También, como perteneciente a su municipio, reclama a Lérida la portada de la antigua iglesia del Salvador de El Tormillo, cuyos elementos fueron trasladados hasta allí para ubicarlos en la portada de la iglesia de San Martín. Se encuentran en el MLDC además cinco fragmentos de arquivolta y un capitel de aquel templo que se reclamaron en 1997.

\subsection{Las piezas del Real Monasterio de Santa María de Sijena en Lérida}

Junto a las obras que fueron objeto del litigio entre Lérida y Barbastro-Monzón, en los fondos del ahora MLDC se encuentran en depósito, procedentes del monasterio de Sijena, un numeroso conjunto de piezas, entre las que se hallan algunas de particular valor artístico. Fueron trasladadas en su mayor parte a lo largo del siglo XX, sobre todo en sus inicios y a principios de los años setenta, en la época del obispo Malla.

En este cenobio áulico ${ }^{48}$, junto a la localidad de Villanueva de Sijena, al sureste de la provincia de Huesca, se instaló una orden de monjas hospitalarias de San Juan de Jerusalén a cuya regla se acogieron en su época de esplendor numerosas princesas y nobles de la Casa de Aragón. Estas dueñas, instruidas y poderosas, cumplieron una amplia labor de mecenazgo, pero hoy sus tesoros están dispersos en colecciones de todo el mundo ${ }^{49}$ y algunos de ellos desaparecidos.

Los desastres de las guerras, en especial la de 1936, contribuyeron al saqueo y el expolio del monasterio. Prestigiosos historiadores del Arte han explicado la conocida y lamentable historia de las pinturas de su sala capitular, que están en depósito en el Museo Nacional de Arte de Cataluña y expuestas en una sala que recrea las dimensiones de su ubicación original.

47 La Tabla de San Pablo fue puerta de un antiguo retablo, representa una figura del santo apóstol de canon muy alargado portando una gran espada. La Tabla de San Pedro y el Calvario, atribuida al Maestro de Viella, representa, en su parte inferior, al santo con los atributos papales acompañado por dos ángeles; en la parte superior de la tabla aparece un Calvario.

${ }_{48}$ Fundado en 1188 por la reina Dña. Sancha, esposa de Alfonso II de Aragón, Sijena se convirtió en uno de los principales focos culturales del reino aragonés durante la Edad Media y el Renacimiento. Fue Panteón Real, Archivo y Corte. Las religiosas sanjuanistas fueron sus regentes desde su fundación hasta principios de 1970, cuando las supervivientes se trasladaron a Barcelona y luego a la localidad catalana de San Cugat del Vallés, al convento de Valdorreix. Actualmente ocupa el monasterio una comunidad de Hermanas de Belén, en régimen de arrendamiento.

49 Es ineludible hacer referencia al trabajo del profesor Naval, que ha estudiado con detenimiento la dispersión del patrimonio artístico altoaragonés y en particular el del Monasterio de Sijena, por lo que remitimos aquí a uno de sus trabajos: NAVAL MAS A., Patrimonio emigrado, Publicaciones y ediciones de El Alto Aragón, Huesca, 1999, pp. 181-245. 
Pero ya antes de la guerra civil, la ruina de la comunidad monástica había acarreado la desaparición paulatina de las joyas artísticas que allí se guardaban, unas veces por traslados en calidad de depósito al Museo Diocesano de Lérida y, otras, por ventas realizadas por las mismas religiosas. Hay que recordar que esta orden religiosa tenía unas singularidades especiales en cuanto a su administración: la congregación de monjas sanjuanistas de Sijena es la propietaria de los bienes que conforman el patrimonio del monasterio y la única persona jurídica con competencias para venderlas o enajenarlas.

Las numerosas pérdidas patrimoniales del monasterio ensombrecen la historia reciente del patrimonio aragonés. La más controvertida fue la venta a la Generalitat, por parte de las monjas de Sijena, de 97 piezas que ya estaban depositadas en los museos de Cataluña. Estas ventas se realizaron en tres fases, entre los años 1983 y 1994. Al tener conocimiento de estas acciones, la Diputación General de Aragón reclamó, el 10 febrero de 1998, el derecho de retracto y, posteriormente, la Generalitat planteó un conflicto de competencias ante el Tribunal Constitucional, que lo admitió a trámite en julio de aquel mismo año, donde sigue hasta la fecha sin resolución. Aunque las monjas — de edad muy avanzada en aquellas fechasactuaron con legitimidad a la hora de vender, los juristas aprecian algunas irregularidades en el proceso de enajenación puesto que, por ejemplo, la Generalitat actuó simultáneamente como comprador y como tasador.

De las piezas vendidas, pueden contemplarse todavía en la exposición permanente del MLDC notables obras artísticas. Merecen especial atención, por su calidad y valor histórico, las cajas sepulcrales de Dña. Isabel de Aragón y de Anjou, de Francisquina de Erill y de Beatriz Cornell, todas del siglo XV, así como algunos fragmentos de los retablos de Santa Ana y de la Infancia de Jesús, en alabastro dorado y policromado fechados entre 1519 y 1521, ambos de la mano de Gabriel Joly, y diversas tablas pintadas pertenecientes a los retablos del Llanto ante Cristo Muerto o de La Piedad, también del siglo XVI. Estas piezas habían entrado en el Museo a título de depósito.

Se hallan asimismo en la exposición, sin tener constancia de que hayan sido vendidas, las dos tablas de San Agustín y San Ambrosio del antiguo retablo del altar mayor del monasterio, del siglo XVI. Pieza fundamental del patrimonio de Sijena es la Silla prioral de Dña. Blanca de Aragón, (ca. 1322), en depósito desde 1904. Es un magnífico trono de madera pintada al temple con motivos hagiográficos, heráldicos (flores de lis y barras aragonesas alusivas a la dinastía real de la priora) y una imagen de la misma doña Blanca asistida por dos dueñas. La deliciosa talla de la Virgen del Parlatorio, de principios del siglo XV, es una de las piezas de Sijena que sufrió los avatares de la guerra civil, regresando al convento para ser trasladada de nuevo a Lérida en 1970.

El obispado de Barbastro-Monzón solicitó, en marzo de 1997, la formación de un catálogo de los bienes patrimoniales de la Orden de San Juan de Jerusalén del cenobio sijenense. Por las mismas fechas, el ayuntamiento de Villanueva de Sije- 
Los bienes de las parroquias altoaragonesas en el Museo de Lérida: de sentencias...

na y la comarca de los Monegros emitieron un manifiesto por el que instaban a los organismos competentes la urgente búsqueda de soluciones que contribuyesen a la devolución de las piezas que integraron en su día los fondos artísticos del monasterio y que se encontraban en los museos catalanes ${ }^{50}$.

La prensa aragonesa recoge las acciones del actual alcalde en demanda de la devolución al monasterio de 136 piezas ${ }^{51}$, acciones que — según el propio edil- se ven limitadas por la demora del pronunciamiento del Tribunal Constitucional en el conflicto de competencias planteado desde Cataluña que se ha referido más arriba.

\section{EL CAMINO DE IDA}

El Museo Católico del Seminario de Lérida se fundaba el 8 de marzo de 1893 por iniciativa del obispo José Meseguer y Costa. Más tarde pasaría a denominarse Museo Diocesano y tendría varias ubicaciones ${ }^{52}$, sin que formalmente se erigiera hasta 1999, con la creación del Consorcio que, como se ha explicado, gestiona el MLDC.

Las diligencias de los sucesivos obispos ilerdenses contribuyeron, en mayor o menor medida, a acrecentar los fondos del Museo ilerdense, pero interesa sobre todo la labor de su fundador para entender el porqué de su creación y la situación actual.

\subsection{Un mitrado amante del arte}

La bibliografía existente sobre el litigio y sobre los orígenes del Museo de Lérida repite hasta la saciedad la cita de una carta de Meseguer en la que explica al rector del seminario ilerdense las razones que le llevaron a la fundación de dicho Museo

«...Deseando fomentar la instrucción de los alumnos del Seminario Conciliar Diocesano, he determinado ampliar la enseñanza que se da en la clase de Arqueología Cristiana, estableciendo un Museo Católico donde pienso reunir los objetos artísticos que pueda haber, practicando cuantas diligencias estén a mi alcance a fin

50 Manifiesto de Villanueva de Sijena, 28 de febrero de 1997.

51 «Llevamos doce años esperando sentencia y no se hace nada», en Heraldo de Aragón, Zaragoza, 4 de noviembre de 2010, p. 5. Las 136 piezas reclamadas para el monasterio son las 97 adquiridas por la Generalitat a las monjas más otras 39 obras procedentes de este que no fueron compradas pero que, por diferentes razones, fueron trasladadas a Cataluña.

52 BERLABÉ JOVÉ, C., «El Museo Diocesano de Lérida. Historia y vicisitudes» en Artigrama..., p. 39. Hasta los años noventa del pasado siglo el Museo Diocesano de Lérida almacenó, más que expuso, las obras religiosas: la adecuación de la iglesia de San Martín permitió la exposición de una parte de ellas, sobre todo la escultura, pero para contemplar algunos de los objetos que se guardaban en la Casa Rectoral era necesario solicitar un permiso. 
de que los alumnos aprendan a distinguir el carácter especial de las obras destinadas a la Religión Católica por las Bellas Artes. [...]

Que los Superiores y alumnos pidan al Cielo bendiga esta obra, y sea estímulo para la aplicación de los que más tarde han de utilizar los conocimientos arqueológicos en bien de la Iglesia y de la Sociedad...» ${ }^{53}$

En efecto, el interés y el celo del obispo Meseguer, personaje sumamente instruido y culto, por proporcionar una correcta formación a los seminaristas de su diócesis era fruto de su extrema sensibilidad hacia el Arte y de la intención de que los futuros párrocos supieran reconocer el valor de los objetos de los templos a los que serían asignados tras su ordenación.

Meseguer conocía perfectamente la situación de las parroquias de su diócesis, muchas de ellas perdidas en un entorno montañoso y expuestas a los robos y a la avidez de los coleccionistas. Fue precisamente la última década del siglo XIX la época en que el coleccionismo estaba especialmente en auge, sobre todo por la fascinación que en los círculos más distinguidos de la burguesía —la catalana en este caso $^{54}$ — venían despertando las obras de época medieval y renacentista: numerosos anticuarios y chamarileros, intermediarios de coleccionistas de renombre, recorrieron las localidades próximas al Pirineo en busca de tratos con los párrocos de sus iglesias, ofreciendo cantidades irrisorias por retablos o escultura devocional o por objetos de sacristía, aprovechando la circunstancia económica de ruina y de abandono de muchos de estos lugares y la precariedad de las condiciones de vida de los sacerdotes que las regían. Prueba del expolio que sufrieron los templos de estas tierras es la ingente cantidad de piezas que ahora enriquecen a Museos y colecciones privadas de todo el mundo.

Ha de señalarse, además, que los sacerdotes recibían periódicamente al obispo en la Santa Visita que este giraba en cumplimiento de sus obligaciones pastorales por cada uno de los pueblos de su diócesis en un itinerario que podía durar semanas. La visita pastoral, que suponía la estancia durante unas horas en cada parroquia, servía para que el prelado conviviera con el párroco y con los feligreses e inspeccionara la adecuación del culto de los templos y el estado de las rectorías. Supo así Meseguer de primera mano la situación de los edificios, de sus miserias y también de sus riquezas. Era el momento para que los sacerdotes rindieran cuentas de su labor pastoral y el momento también de alcanzar algún favor del obispo.

${ }^{53}$ Carta de José Meseguer y Costa dirigida al rector del seminario de Lérida, fechada el 7 de marzo de 1893. Transcrita en FUSTÉ I VILA, J., El Museu Arqueològic de la Diocesi de Lleida, Imprenta Mariana, Lleida, 1924, pp. 5 y 6.

54 BARRACHINA, J., «A l'entorn de Frederic Marès. Una aproximació al col·leccionisme català d'escultura medieval» en La col/lecció somiada. Escultura medieval a les col/leccions catalanes, Quaderns del Museu Frederic Marès, núm. 7, Barcelona, 2002, pp. 25 y 38-39; GARCÍA GUATAS, M., «Recuperación del patrimonio cultural de Aragón», en Annales, núm. XII-XIII, 1995-2000, Fundación Ramón J. Sender, Barbastro, p. 158. 
Los bienes de las parroquias altoaragonesas en el Museo de Lérida: de sentencias...

Las diligencias que Meseguer y sus sucesores en la mitra ilerdense hicieron para incrementar los objetos que habían de ocupar las salas del Museo que se establecería en el Seminario de Lérida son hoy el argumento de las discusiones sobre la propiedad de los bienes, pero fue el mismo Meseguer quien dio el único argumento posible, explicando que los había trasladado

«...cuando han sido dignos de figurar en él. Dando generalmente alguna cosa a las Iglesias, más como un afectuoso recuerdo que como precio de mercadería, porque no es decoroso descender al terreno de los contratos, pero las parroquias no han sido perjudicadas, porque gracias a Dios no necesitamos aprender el afecto que las debemos de ningún explotador de los bienes eclesiásticos, y siempre hemos opuesto nuestra caridad aunque débil, a la desmedida codicia de estos mercaderes... ${ }^{55}$

Meseguer, licenciado en Derecho Civil y Canónico y doctor en Teología y Cánones, era perfectamente consciente de que ni obispo ni párrocos son dueños de los bienes de su diócesis o parroquias y que solo los administran. Sin duda era conocedor, además, de la circular del obispo Urquinaona, de 21 de agosto de 1879 que, basándose en las Decretales e inspirado por la encíclica Aeterni Patris de León XIII, de 4 de agosto de aquel mismo año

«...prohíbe de nuevo la permuta, venta, cesión, enajenación de cualquier utensilio, ornamento, por viejo que sea o esté; de toda caja, de todo manuscrito, libro, lápida, cuadro, retablo, moneda, banco y de todo otro objeto que se recomiende por su mérito artístico, o por el solo sabor de su antigüedad... $\gg^{56}$

Sabía además que solo él, como obispo, podía autorizar a los párrocos la enajenación de los bienes eclesiásticos y que, cuando se trataba de bienes precio$\operatorname{sos}^{57}$, era necesaria una licencia de la Sede Apostólica. También conocía Meseguer que para la enajenación de bienes eclesiásticos habían de observarse requisitos imprescindibles, a saber: primero, la tasación de la cosa por peritos hon-

55 MESEGUER Y COSTA, J., «Circular sobre enajenación de los objetos de las iglesias» en BOEDL, T. XV,1905, p. 446. Esta circular está fechada el 8 de noviembre de 1903. A no ser por este escrito podría pensarse que Meseguer tenía una voluntad de apropiación de las piezas a la manera de un coleccionista, cuando en realidad su interés siempre fue el de la conservación.

56 Glosado en TURBINO, Fr. M., «Los monumentos del arte cristiano y la Circular del Sr. Obispo Urquinaona de Barcelona» en La Ilustración Española y Americana, Año XIII, septiembre de 1879, Suplemento XXVI, pp. 202-203 y 206.

57 La calificación de obras preciosas, que conllevaría la consiguiente necesidad del permiso de la Sede Apostólica para su enajenación, fue una de las cuestiones debatidas desde el principio por los tribunales canónicos. Los bienes preciosos, que forman una categoría particular dentro de los bienes eclesiásticos, son a efectos de la legislación canónica, los bienes corporales (ya sean inmuebles o muebles) o incorporales que posean un valor notable por razón de arte, o de la historia, o de la materia (definición del CIC 1917, c. 1497.2).El Razonamiento Jurídico Segundo del Decreto de la Congregación para los Obispos de 2005 argumenta la necesidad de esta licencia, basándose en el CIC 1917, c. 1532.1,1, y c. 1530.1.3.

EI CIC 1983, vigente en la actualidad, no contempla la clasificación de bienes eclesiásticos ni la definición de bienes preciosos. Véase TEJÓN SÁNCHEZ, R., Confesiones religiosas y patrimonio cultural, Ministerio de Justicia, Madrid, 2008, pp. 59-60. Véase también IGUACÉN BORAU, D., op. cit, p. 210. 
rados hecha por escrito; segundo, la causa justa, es decir, necesidad urgente o utilidad manifiesta de la Iglesia, o piedad, y tercero, la ya citada de la licencia de un superior legítimo, sin la cual se invalida el acto.

\subsection{El traslado de las piezas}

La forma en que las piezas fueron a parar el Museo, unas veces ofrecidas por los párrocos y otras requeridas - e incluso exigidas - por el obispo, está documentada generalmente en la correspondencia que se guarda en el Archivo Diocesano de Lérida ${ }^{58}$. Durante el proceso canónico, tanto la Comisión de Expertos como el Ejecutor del Decreto de la Nunciatura la estudiaron, por lo que aparecen continuas referencias a ella en los sucesivos Razonamientos Jurídicos de aquel ${ }^{59}$. En ningún momento, por parte de las instancias eclesiásticas a lo largo del proceso jurídico canónico se les da a estos documentos el valor de pruebas o certificados de compra que, sin embargo, se les adjudica ahora desde Lérida.

Ejemplos del modo de hacer de Meseguer para conseguir el traslado de las piezas desde las parroquias aragonesas y de las diferentes actitudes de las poblaciones se pueden rastrear en sus escritos, recogidos en el Boletín Oficial Eclesiástico de la Diócesis de Lérida (BOEDL) y, sobre todo, en su diario de Santa Visita.

En una de las visitas que realizó Meseguer, el 20 de mayo de 1893, conoció el estado de ruina de la vieja iglesia del Salvador de El Tormillo y la necesidad de reparaciones en los tejados y la torre de la iglesia de Santa María de la Asunción ${ }^{60}$, que sigue siendo hoy la utilizada para el culto. En ese mismo momento se estaba realizando en la capital leridana la recuperación de la iglesia románica de San Martín que, según refiere el mismo Meseguer era «del mismo orden». El prelado solicitó el traslado de dicha portada y el ayuntamiento de la localidad accedió a ello a lo que el obispado respondió, como se refiere en una carta pastoral

«...dando una respetable limosna para las obras que se estaban haciendo en la torre de la actual iglesia de aquella parroquia...» 61

\footnotetext{
58 Hay que señalar que, hasta el momento, no se ha tenido acceso a estos documentos en el Archivo Diocesano de Lérida ya que, según su Archivero, no puede consultarse por constituir una de las pruebas del proceso jurídico —en el momento de escribir este artículo, el pleito civil-, si bien es cierto que los documentos que en adelante se citarán sí pudieron ser consultados por la autora de este artículo en dicho Archivo.

La documentación que atañe al envío de las piezas a Lérida por parte de los párrocos fue estudiada por Berlabé Jové y está publicada en su tesis doctoral. Véase supra nota 28.

59 AZNAR GIL, F. R. y ROMÁN SÁNCHEZ, R. (coords.), Los bienes artísticos..., op. cit., pp. 167-188.

60 Archivo de la Catedral de Lérida (ACL), Visitas pastorales 33, Registro de Santa Visita, fol. 65 r. y v., mayo de 1883. Manuscrito del obispo Meseguer.

61 «Carta pastoral» en Boletín Oficial Eclesiástico de la Diócesis de Lérida (BOEDL), T. V, 26 de agosto de 1895, pp. 315-321. Véase también FUSTÉ I VILA, J., op. cit., p. 8.
} 
Los bienes de las parroquias altoaragonesas en el Museo de Lérida: de sentencias...

Ninguna noticia tenemos sobre la posible compensación económica por el traslado del Frontal de altar del Salvador desde la parroquia de Berbegal al Museo del Seminario de Lérida. En el Archivo de la Catedral de Lérida se conservan los documentos que atestiguan la solicitud al obispado por parte del entonces párroco, Manuel Quintillá, para poder financiar los necesarios arreglos en la torre gótica ${ }^{62}$, de la que se había desprendido buena parte de su cuerpo alto en 1850.

Durante siglos el frontal se había conservado en su ubicación original, en el ara adosada al testero de la antigua colegiata ${ }^{63}$, quedando oculto a la vista de los feligreses tras la construcción de un gran retablo de gusto barroco que ocupó el altar mayor. Sin embargo, a principios de septiembre de 1903, apenas unos días después de la muerte de Quintillá, ya estaba en el Museo del Seminario ${ }^{64}$. La correspondencia que se ha podido consultar en el Archivo Diocesano de Lérida revela que Meseguer, nada más tener noticia del fallecimiento del cura, envió a un presbítero a Berbegal con instrucciones expresas para hacerse cargo de la parroquia ${ }^{65} y$ este se apresuró a entregar el frontal —que estaba bajo llave- al párroco de El Tormillo, quien lo remitiría rápidamente a Lérida. El BOEDL recoge su entrada el año siguiente ${ }^{66}$. La torre de Berbegal tendría que esperar a las aportaciones vecinales y la ayuda del Estado con las que se efectuaría su reparación en 193067.

En ocasiones, la decisión de Meseguer de trasladar algunas obras al Museo originó la protesta airada de los estamentos municipales de los pueblos aragoneses. Un ejemplo de la imposición de su voluntad contra los alcaldes o los feligreses son las tablas del retablo de Binaced, el valioso conjunto del Nacimiento y la Epifanía, que el obispo mandó retirar del lugar que ocupaban como puertas de un armario de su sacristía. Al enterarse, el alcalde se negó a que las tablas salieran de la población a lo que el obispo respondería escribiendo al párroco en estos términos

«...Había indicado a usted las enviase [dichas tablas] a ésta sin manifestarle el destino porque puedo disponer de todos los objetos del culto de la Diócesis para restaurarlos por mi mismo si lo estimo conveniente, como he hecho con algunos a mis expensas, cuando recibo un oficio de esa alcaldía pidiéndome ordene a usted coloque nuevamente las puertas donde se hallaban. Repito a usted la orden de quitar estas tablas y por ahora sacarlas a la veneración de los fieles en el sitio de la iglesia que a usted parezca más conveniente, prohibiéndole bajo apercibimiento obedezca usted en este asunto a ninguna autoridad más que a la única que manda en la Iglesia, reservándome proceder contra el firmante del oficio en la forma que disponen las leyes... ${ }^{68}$

\footnotetext{
62 ACL, Visitas Pastorales, 35, fol. 76 v.

63 CAVERO BLECUA, M., La villa de Berbegal y su colegiata de Santa María la Blanca, Tipografía Corrales, Barbastro, 1967, [p. 28].

64 BERLABÉ JOVÉ, C., El Museu diocesà de Lleida..., Vol. 2, p. 385.

65 Archivo de la Diócesis de Lérida, (ADL), Meseguer, Caja 4 Berbegal. Cartas de Martín Mayora al obispo Meseguer datadas en Berbegal, a 26 y 28 de agosto de 1903.

66 BOEDL, T. XIV, 9 de marzo de 1904, p. 124.

67 «Berbegal arregla su gigantesca torre» en Heraldo de Aragón, Zaragoza, 27 de abril de 1930, p. 9.

68 ADL, Copiador de Oficios, 3, fol. 97 r.
} 
Las Tablas del Nacimiento y la Epifanía, la Ascensión y Pentecostés ingresaron finalmente en el Museo del Seminario en 1898, junto con otras tres más procedentes de Binaced ${ }^{69}$.

Algunas de las piezas que Meseguer recogió para el Museo tenían más valor inmaterial que artístico. Es el caso de la Arqueta de San Ramón de Roda de Isábena: una urna de madera tachonada con herrajes dispuestos de manera geométrica, en la que se habían recogido los restos de San Ramón, obispo de Roda (1104-1126), cuya veneración en tierras ribagorzanas tiene un arraigo profundo y secular. Meseguer pretendía cambiar la urna del primer tercio del siglo XVII, por otra más lujosa y moderna, depositando en esta las reliquias y la cerradura de la original, y haciéndose enviar la antigua a Lérida. El acto se consumó, pero en aquel momento los habitantes de los pueblos cercanos a Roda de Isábena protestaron públicamente por lo que entendieron una profanación. No obstante, la arqueta está en la actualidad en el MLDC.

\section{EN EL MUSEO}

Meseguer y los obispos que le sucedieron en la mitra de Lérida y que con sus gestiones incrementaron los fondos del Museo gratificaron a las parroquias de las que procedían las piezas unas veces con otros objetos de culto más modernos, otras, con cuantías económicas que habían de servir para realizar obras para el acondicionamiento y mejora en los templos y, otras, como hemos visto en Berbegal, con nada.

Según recoge el «Informe sobre el Contencioso entre las diócesis de Lérida y Barbastro Monzón, de 1 de diciembre de 1997», emitido por la Comisión de expertos, el entonces obispo de Lérida expuso en el año 1996 que

«Prácticamente todas las piezas que se conservan fueron entregadas espontáneamente o por sugerencia del Obispo, con destino al museo diocesano: en muchos casos se trata de piezas que estaban arrinconadas en los desvanes o en las sacristías de los templos, es decir, no quedaban expuestas a la veneración de los fieles o estaban fuera de uso.

Algunas piezas, muy pocas, fueron entregadas voluntaria y directamente por los párrocos o personas que las tenían en su poder; en algún caso la entrega se hizo como exigencia de la donación a la parroquia de una cantidad por parte del Obispado para determinadas actuaciones parroquiales, que de otra forma no hubieran recibido. [...]

No consta por escrito que se cumplieran las formalidades canónicas para la enajenación ` $^{70}$

69 BOEDL, T. IX, 17 de marzo de 1899, p. 101.

70 AZNAR GIL, F. R. y ROMÁN SÁNCHEZ, R., op. cit., p. 116-117. 
Los bienes de las parroquias altoaragonesas en el Museo de Lérida: de sentencias...

Es imposible saber en la actualidad qué número total de piezas procedentes de las parroquias aragonesas se encuentran depositadas en el MLDC. Aunque en el $B O E D L$ se registró la entrada de las piezas en el Museo desde 1895 a 1905, pocas veces esta anotación se hacía de una manera clara y la lectura de sus páginas lleva a la confusión ${ }^{71}$. Pero el escrito de uno de los primeros conservadores del Museo permite - como se va a ver seguidamente- conocer el cuidado y la intención con la que desde un primer momento se conservaron todos los objetos procedentes de las parroquias.

\subsection{Intentos de catalogación}

En el BOEDL de 8 de marzo de 1898 se explica que, si bien la anotación se había descuidado en un principio, los objetos que se iban recibiendo eran numerados, clasificados por épocas y anotados en un registro que había permitido la formación de un catálogo ${ }^{72}$.

En su trabajo El Museu Arqueològic de la Diòcesi de Lleida, Joan Fusté i Vila, conservador del Museo Diocesano entre los años 1916 y 1925, refiere que el personal a cargo de dicho Museo hizo un registro cuidadoso de las piezas desde el primer momento. Sin embargo, también explicaba Fusté que

«...En ningún museo, posiblemente, sea tan difícil la catalogación como en el de Lérida. Descuidada con toda la deliberación, aunque con un fin plausible, la anotación de la procedencia de las antigüedades de tal manera que nadie pudiese venir con inoportunas reclamaciones, y conociéndose por el Boletín solamente la de las que le parecía al Excmo. Sr. Obispo, hoy se había hecho muy laboriosa la tarea de averiguar la procedencia, porque nunca había tenido Conservador y porque ya están muertos los clérigos y particulares que habían hecho el ingreso, y si bien es cierto que todavía vive el Excmo. Sr. Arzobispo de Granada, ¿cómo podría recordar la procedencia de tantas y tantas piezas que casi llegan a dos mil?...»73

Hay que notar que, a pesar de esta intencionalidad evidente de ocultar la procedencia de las piezas en previsión de posibles reclamaciones - que queda recogida en estas frases - la propiedad siempre estuvo clara para quienes las custodiaban. En las mismas páginas explicaba Fusté:

«...Los objetos son: o propios del Museo o guardados en depósito. Los propios se adquieren en buena parte por donativo, otros se compraron a particulares y

${ }^{71}$ La siguiente cita demuestra la dificultad de determinar cuál es la procedencia de cada pieza. Véase BOEDL, T. VII, 6 de marzo de 1897, p. 118-119.

«...Dos cruces grandes, una con restos de esmalte. Otras pequeñas. Varios incensarios, unos góticos, otros bizantinos, una naveta y un portapaz con restos de esmalte. Bandejas de cobre con relieves e inscripciones, atentamente enviadas por los Sres. Párroco Arcipreste de Morillo de Liena, Ecónomo de Capella y regente de Viu de Llevata...»

72 BOEDL,T. VIII, 8 de marzo de 1898, p. 128.

73 FUSTÉ I VILA, J., op. cit., p. 29. 
otros fueron obtenidos a cambio de idénticos objetos pero modernos [...] Los depósitos son de dos maneras: voluntarios y forzados. Constituyen los segundos los objetos pertenecientes a las parroquias o iglesias dependientes que no los quieren vender o permutar y como ofrecen riesgo tanto para su debida conservación como por estar expuestos a robo, el obispo los hace ingresar forzosamente al Museo reservando a los dueños su propiedad... ${ }^{74}$

\subsection{La labor de conservación}

Es indudable que Meseguer contribuyó, al recoger las piezas de las parroquias, a la conservación de estas ya que, de haber permanecido en ellas, es muy posible que hubieran sido robadas, vendidas, o, peor aún, hubieran ardido durante la guerra civil en el interior de los templos o en hogueras en las plazas de los pueblos. La línea del frente dividió en dos zonas la provincia de Huesca hasta la primavera del 38 , situándose las tropas republicanas al este de la capital. Las columnas anarquistas que habían salido de Barcelona a partir del 19 julio de 1936 cometerían numerosos atropellos en el patrimonio artístico de esta parte oriental de la provincia, enarbolando una furia iconoclasta que arrastró también a algunos de los habitantes de los pueblos aragoneses. La provincia de Huesca fue, escribía Chamoso Lamas en 1943, la que más sufrió en su patrimonio artístico ${ }^{75}$. Álvarez Lopera se refiere al «...holocausto del acervo artístico aragonés... »76

En Lérida, los agentes republicanos de Patrimonio instalaron, en el antiguo Hospital de Santa María, el Museo del Pueblo, donde se depositaron las obras del Museo del Seminario, además de otros fondos, así como las piezas recogidas en la zona oriental de Aragón (Roda de Isábena, Alquézar, Sijena...) que más tarde se trasladarían a la ermita de Butsenit ${ }^{77}$. Una vez las tropas franquistas tomaron Lérida, los depósitos de Butsenit, a expensas del general Moscardó serían transportados hasta Zaragoza para protegerlos del fragor del conflicto, donde podrían ser contemplados al acabar la guerra en la exposición Arte recuperado. Desde la ca-

\footnotetext{
74 Ibídem, p. 27.

75 CHAMOSO LAMAS, M., Noticia de los trabajos realizados por el Servicio de Recuperación Artística, publicado en el Boletín de la Sociedad Española de la Excursiones, Tomo LI, Madrid, 1943, p. 24. Es muy interesante también el artículo de BUESA CONDE, D., «El patrimonio artístico altoaragonés. Emigraciones y destrucción» en Signos. Arte y cultura en el Alto Aragón oriental, Diputación Provincial de Huesca-Gobierno de Aragón, 1993, pp. 31-45.

76 ÁLVAREZ LOPERA, J., La política de bienes culturales del gobierno republicano durante la guerra civil española, Ministerio de Cultura, Madrid, 1982, Vol. 2, p. 128.

Por otra parte, los agentes republicanos de la Junta del Tesoro Artístico intentaron salvar el patrimonio artístico del atropello iconoclasta de los milicianos, pero en muchas ocasiones chocaron con la circunstancia de que quienes estaban el mando en las poblaciones, algunas de ellas convertidas en colectividades agrarias, tenían necesidades más urgentes que las de proteger las obras de arte religioso, que veían casi siempre, como símbolo de poder eclesiástico identificándolo con la opresión sufrida en el pasado.

77 Chamoso lamas, M., op. cit., p. 46; MONREAL Y TEJADA, L., Arte y Guerra Civil, Ed. La Val d'Onsera, Angüés, 1999, p. 55.
} 
Los bienes de las parroquias altoaragonesas en el Museo de Lérida: de sentencias...

pital aragonesa las piezas se reenviaron a sus lugares de origen: en Lérida, el entonces obispo, Moll y Salord, se haría cargo de todas las obras sacras que habían estado anteriormente en el Museo del Seminario - y de algunas otras del Museo del Pueblo- en calidad de titular de la diócesis, que no de propietario.

La diócesis leridana, no obstante, siempre dispuso de las piezas aragonesas, incluyéndolas en la nómina de las obras de la iglesia catalana. Basta para ello repasar los catálogos de las importantes exposiciones que han tenido lugar a lo largo del siglo XX y a las que viajaron las obras más destacadas. Un ejemplo claro de ello es la exposición El Arte en España durante la Internacional de Barcelona de 1929 , en cuyo catálogo la procedencia original de las más de veinte piezas de la parte oriental de Huesca que allí se expusieron y que ya estaban depositadas en el Museo leridano no se explicita, sino que se alude exclusivamente a la procedencia del «Museo del Seminario de Lérida».

Al margen de estas acciones, como se ha reiterado hasta aquí, el obispado de Lérida ha contribuido, como era obligación y expreso deseo de su fundador, al mantenimiento del conjunto y a la restauración de las piezas que ahora, como legítimas propietarias, reclaman las parroquias oscenses.

El buen estado de las obras que se exponen en el MLDC o son objeto de devoción en la iglesia de San Lorenzo y de algunas de las que se conservan en la reserva, avala la atención y las intervenciones a que han sido sometidas, sobre todo a partir de los años ochenta del pasado siglo y, en muchos casos, gracias a fondos autonómicos catalanes. El celo y la pericia de los profesionales quedan demostrados sin duda en el estado actual de piezas como el Frontal de Buira, la Piedad de Ardanué, o el San Juan Bautista de Zaidín, así como en otras que, a pesar de haber sido reclamadas en su día por la diócesis de Barbastro-Monzón, no han de ser devueltas por no haberse podido demostrar la parroquia de procedencia, como el caso del Retablo de la Virgen del Rosario o la Virgen de las Uvas y, sin duda, en las destacadas piezas de Sijena que están a la vista del público en las salas de dicho Museo.

\section{CONSIDERACIONES FINALES ${ }^{78}$}

Expertos aragoneses en patrimonio vienen aconsejando que no se lleven a posiciones extremas los postulados y que, si bien es legítimo vindicar la propiedad de las piezas, han de evitarse actitudes demagógicas e intransigentes que solo contribuyen a enrarecer las relaciones entre dos comunidades que, por su proximidad y por su historia común, están obligadas a entenderse.

78 Quiero dejar constancia de mi agradecimiento a quienes, desde sus actividades docentes, eclesiásticas, jurídicas, administrativas o de gestión del patrimonio, me han ayudado a comprender el entramado de este asunto. 
Las actitudes de los dos gobiernos autónomos respecto al litigio por el arte sacro han sido muy distintas y el enquistamiento del problema ha originado debates políticos internos y fricciones entre ambos. Desde el seno eclesiástico se reconoce que se ha de poner fin a esta situación porque está generando un grave daño a la comunidad cristiana y que la misma Iglesia debe demostrar su capacidad para imponer la obediencia de sus reglas. En diferentes medios de comunicación se ha puesto en relieve la diplomacia y la cautela con que el obispado aragonés ha llevado este tema. $\mathrm{E}$ incluso, significativamente, desde algún periódico catalán se ha afirmado que

«...Politizar este tema ha sido un error; convertirlo en una discusión entre territorios, una equivocación, y querer suplantar la autoridad de la Iglesia en esta cuestión, un disparate [...] Plantear desde Catalunya la cuestión como una victoria de unos sobre otros es un error. Máxime cuando la razón estaba más del lado aragonés...»79

\subsection{Sobre la reclamación por parte de las parroquias}

En el devenir de un siglo ha variado mucho la situación económica y social de las comunidades rurales oscenses mediatizada, a principios de siglo XX, por unas formas de vida y por unas relaciones con los órganos de poder, entre ellos el eclesiástico, muy distintas a las actuales. En este sentido, no puede hacerse una crítica sobre la pasividad o el desinterés que las poblaciones mostraron hace un siglo ante las disposiciones que tomaba su obispo respecto al patrimonio de sus parroquias: era la decisión de la autoridad en esa materia y, de buen o mal grado, terminaban por acatarla.

Por lo mismo, tampoco se debe menospreciar la atención que los actuales representantes de las comunidades locales oscenses vienen mostrando hacia la recuperación de su patrimonio, que a veces se ha tachado de demagógica u oportunista. A esas entidades y a las diócesis aragonesas se les ha imputado que no hayan hecho antes esta reclamación a Lérida: desde la primera segregación de parroquias, en 1955, ya se podía haber revisado la situación de algunos bienes, sobre todo los pertenecientes a las parroquias que pasaron entonces a Huesca, a sabiendas de que la mitra oscense cerraba en aquel momento el proceso ${ }^{80}$. Cuatro de las diecisiete parroquias que en aquel momento se integraron a la diócesis barbastrense tenían bienes depositados en el Museo Diocesano de Lérida. Tampoco se solicitaron estos entonces, en espera a la definitiva concordancia de los térmi-

79 «El fin de un litigio» en La Vanguardia, Barcelona, 28 de octubre de 2010, p. 2.

80 En 1967, Miguel Cavero concluía su opúsculo sobre la iglesia de Berbegal expresando la voluntad de la población y del párroco de que el Frontal de altar del Salvador regresase a su lugar original en el altar mayor. No tengo constancia de que estas demandas se plantearan formalmente ante ninguna institución, pero dejan patente el conocimiento y el interés por recuperar la pieza. Véase CAVERO BLECUA, M., op. cit., [p. 30]. 
Los bienes de las parroquias altoaragonesas en el Museo de Lérida: de sentencias...

nos diocesanos con los administrativos civiles, sin imaginar ni que dicha concordancia se retrasara tanto, ni que la reclamación de los bienes ocasionaría semejante discordia entre dos diócesis hermanas.

El 15 de diciembre de 2010 se inauguraba el nuevo Museo Diocesano de Barbastro-Monzón pensado para albergar las piezas que protagonizan el litigio junto a los fondos que ya formaban parte de dicho Museo y se custodiaban en anteriores instalaciones desde 1978. Las autoridades eclesiásticas y civiles aragonesas se reafirmaron, durante ese acto, en la confianza de que pronto los bienes se expondrán en este nuevo Museo. Será ese el momento en que se planteará otra cuestión interna, puesto que algunos de los ayuntamientos de las parroquias propietarias - y también las pertenecientes a la diócesis de Huesca- han manifestado su interés en que los bienes retornen a sus lugares de origen.

\subsection{Sobre los argumentos esgrimidos desde Cataluña}

La cuestión de la unidad museística que invocan algunas instituciones catalanas amparándose en la doctrina del ICOM podría aceptarse por el hecho de que el actual MLDC cumple perfectamente con el principio fundamental de divulgación y protección de las piezas que en él se conservan. El MLDC es hoy el magnífico contenedor de un conglomerado de bienes muy diferentes entre sí, agrupados en Museos antes separados y unidos coyunturalmente, puesto que contribuyeron a la formación del Consorcio, como se ha dicho, diferentes entidades locales y comarcales leridanas además de la diócesis.

Sin embargo, son precisamente las circunstancias de esta adscripción las que enturbian el argumento de la integridad de la colección puesto que, cuando dicho Consorcio se constituyó formalmente en 1999, no debieron haberse incluido en él piezas cuya propiedad no pertenecía a la diócesis de Lérida y, por tanto, tampoco son propiedad del Museo, aunque pasasen a formar parte de sus fondos. Es más, la adquisición inicial estaba a título de depósito, como ya había señalado el Decreto de la Nunciatura de 29 de junio de 1998, y el ICOM —que no habla de «integridad» sino de «permanencia» de las colecciones- advierte que han de respetarse siempre los derechos del propietario, esto es, de las parroquias. El código deontológico del ICOM recomienda, al tratar sobre la adquisición de las colecciones, que

«...Un museo no debe adquirir ningún objeto o espécimen por compra, donación, préstamo, legado o intercambio sin que esté seguro de la existencia de un título de propiedad válido. Una prueba de propiedad o la posesión legal de un objeto en un país determinado no constituyen forzosamente un título de propiedad válido.

\section{$[\ldots]$}


Cuando un museo tiene un derecho jurídico para dar de baja o ha adquirido objetos sometidos a condiciones de baja, deben respetarse plenamente los requisitos y procedimientos legales o de otro tipo. Si la adquisición inicial estaba sometida a restricciones obligatorias o de otro tipo, deben respetarse, a no ser que se demuestre claramente que son imposibles de cumplir o sumamente perjudiciales para la institución.... ${ }^{81}$

\subsection{Sobre el «valor» de la identidad}

Cabría preguntarse, también, sobre si los argumentos de los que se sirve el citado informe del IEC respecto al valor como conjunto de la colección diocesana son superiores al valor que, para la historia y la identidad de las poblaciones cuyas comunidades parroquiales las hicieron posibles, tiene cada una de estas piezas.

La pertenencia de las tierras orientales oscenses a la diócesis de Lérida es un hecho histórico, pero hay que entender que, ante todo, junto a un territorio mucho más amplio, formaron parte de la Corona de Aragón y que su historia está condicionada no solo por vinculaciones eclesiásticas, sino también por relaciones señoriales, comerciales y de otros tipos ${ }^{82}$. Por tanto, el valor de cada una de las piezas es el que es, es decir, que los bienes tienen valores patrimoniales individuales por sí mismos: no solo se trata de piezas artísticas, sino de objetos de devoción a los que todo el conflicto en que se han visto envueltos les ha conferido un valor añadido como expresión de identidad, de lucha por reconocimiento de unos derechos, convirtiéndolos en bellísimos iconos de una reivindicación.

En la historia particular de cada uno de los bienes reclamados desde Aragón habrán de tenerse en cuenta ya no solo las circunstancias de su creación, o que hayan permanecido un siglo en el Museo de la diócesis leridana sino, sobre todo, el porqué y el cómo fueron trasladados hasta allí.

${ }^{81}$ Código de deontología del ICOM, puntos 2.2 y 2.12, respectivamente. Son muy interesantes las reflexiones sobre la importancia del mantenimiento de las colecciones museísticas y las posibles excepciones que hace en su artículo la profesora HERNÁNDEZ MARTíNEZ, A., "Una historia incompleta: el Patrimonio aragonés disperso" en Artigrama, núm. 20, Departamento de Historia del Arte, Universidad de Zaragoza, 2005, pp. 24-28; así mismo, este tema está también abordado desde una perspectiva antropológica en ROMA I RIU, J., «Patrimonio transfugado y construcción de la identidad», en Ripacurtia, núm. 1, La identidad en la Ribagorza y sus zonas de influencia, Centro de Estudios Ribagorzanos, Benabarre, 2003, pp. 13-25.

82 De hecho, la creación de alguna de las piezas como el Frontal de altar de Berbegal, data de siglos anteriores a la adscripción de su arciprestazgo a la mitra leridana, en 1571, y la calidad de la propia pieza transmite, por sí misma, la importancia que la población tenía en la época medieval.

Las tablas de Binaced, obra de Jaume Ferrer, formaron parte del ajuar de esa parroquia. La historiografía leridana las vincula con la producción de este artista para la Seu Vella de Lérida, explicando su ubicación «accidental» en Aragón por un traslado hecho desde la catedral a raíz de su expolio por parte de las tropas francesas. Sin embargo, esta reconocida pieza pudo ser, como tantos ricos retablos que decoraron los templos aragoneses, el encargo por parte de un donante para la parroquia aragonesa a un artista de moda de la época. Ninguna de las dos hipótesis ha sido probada documentalmente. 


\subsection{Sobre la situación quince años después de iniciarse el litigio}

El reciente acuerdo de 27 de octubre de 2010 entre los obispos de Lérida y Barbastro-Monzón ante el nuncio apostólico manifiesta -en lo que de él ha trascendido a través de los medios de comunicación - la disposición de la Iglesia para alcanzar un consenso basado en el hecho incontrovertible de la titularidad por parte de las parroquias aragonesas. Los dos prelados se comprometieron a luchar conjuntamente contra los obstáculos jurídicos que se presenten para su devolución y a cooperar para que, junto a las instituciones públicas, se favorezca la difusión y el conocimiento de los valores culturales de este patrimonio mediante la organización de exposiciones conjuntas o la realización de copias de las obras más interesantes, entre otras actuaciones.

El obispado de Barbastro-Monzón ha declarado en repetidas ocasiones que cualquier compromiso institucional pasa previamente por el reconocimiento de la propiedad por parte de las parroquias y la devolución de las piezas. Por su parte, al día siguiente de la reunión de los obispos, el Departament de Cultura de la Generalitat se pronunciaba sobre el acuerdo de estos manifestando que la colección de obras de arte del MLDC está amparada por la Ley catalana de Patrimonio Cultural y por las sucesivas resoluciones del parlamento catalán y reiterando la legitimidad y la unidad de la colección del MLDC.

Así mismo, el auto del tribunal civil que denegó el exequatur recuerda que la Iglesia goza de plena autonomía en su propio ámbito dentro del marco del acuerdo internacional suscrito con el Estado español en 1979, por lo que

«...si cualquier autoridad en el ámbito del Estado español impide o pone obstáculos a la ejecución de la resolución eclesiástica, deberían operar los sistemas previstos por el Derecho Internacional...»83

Pero en cuestiones de patrimonio expoliado o de gestión museística la aplicación de las normativas y recomendaciones internacionales se complica en el momento que el ámbito se reduce al territorio estatal — precedentes relacionados con Cataluña están en la mente de todos-. Y aún más en este caso particular puesto que, a día de hoy siguen existiendo muchos vínculos de buena vecindad entre las gentes de las comarcas limítrofes. Por tanto, habrá que buscar una solución que no lesione las sensibilidades de unos ni de otros y, en este sentido, el acuerdo entre los obispos parece una apuesta avanzada y factible puesto que las modernas tecnologías permiten la duplicación de las piezas, de tal manera que se pueda conservar en el Museo la copia de la pieza en concreto, una vez que se hayan ejecutado los pertinentes estudios y la devolución de aquellas a los propietarios que las reclamen.

${ }^{83}$ Fragmento de la sentencia emitida por el Juez de Barbastro. Citado en AZNAR GIL, F. R. y ROMÁN SÁNCHEZ, R., «La iglesia frente a sus responsabilidades» en Heraldo de Aragón, Zaragoza, 10 de junio de 2010, p. 23. 
Este laberíntico conflicto tiene distintas dimensiones de las cuales posee un considerable peso específico el valor del patrimonio como generador de identidades y, en particular, los objetos sagrados, puesto que las creencias y las devociones constituyen una parte trascendental en la riqueza cultural de los pueblos. Las comunidades locales son conscientes de que a ellas les corresponde la restitución $y$, puesto que la obra de arte ha de entenderse en el contexto para el que fue pensada, no es impropia esta otra reclamación siempre que - aparte de que su seguridad esté exquisitamente garantizada - se entiendan como verdaderos objetos de devoción y de historia, y no solo como un reclamo turístico.

El litigio por las piezas de arte sacro ha generado múltiples discrepancias de orden social y político que se reflejan, casi a diario, en los medios de comunicación de las dos comunidades autónomas. Se ha tratado de recoger, en estas páginas, las intenciones y los modos de operar de los agentes implicados en todo el proceso y las repercusiones de sus acciones y, también, de sus omisiones.

Nuestra sociedad democrática tiene que encontrar las soluciones para cerrar este conflicto demasiado largo en el tiempo, sin poner obstáculos, ni jurídicos ni políticos, para el cumplimiento de los acuerdos establecidos en un asunto en que la Iglesia tiene todas las competencias. Puede ser que la única solución a su complejidad pase por la negociación y la colaboración institucionales, pero si las posturas siguen enrocadas, no harán más que prolongarlo, abriendo una profunda cicatriz en la historia de dos comunidades entre las que siempre se han levantado puentes para el entendimiento. 